\title{
The Downside of Good Peers: How Classroom Composition Differentially Affects Men's and Women's STEM Persistence*
}

\author{
Stefanie Fischer \\ Cal Poly State University, San Luis Obispo \\ sjfische@calpoly.edu
}

August 11, 2016

\begin{abstract}
This paper investigates whether class composition can help explain why women are disproportionately more likely to fall out of the "STEM" pipeline. Identification comes from a standardized enrollment process at a large public university that essentially randomly assigns freshmen to different mandatory introductory chemistry lectures. Using administrative data, I find that women who are enrolled in a class with higher ability peers are less likely to graduate with a STEM degree, while men's STEM persistence is unaffected. The effect is largest for women in the bottom third of the ability distribution. I rule out that this is driven solely by grades.
\end{abstract}

JEL Codes: I20, I230, I240

Keywords: Higher Education, Gender, STEM, Classroom Composition Effects

${ }^{*}$ I thank the office of Institutional Research, Planning and Assessment at UC Santa Barbara for access to administrative data. This paper has benefited from helpful comments from Kelly Bedard, Peter Kuhn, Shelly Lundberg, Dick Startz, Maya Rossin-Slater, Jon Sonstelie, UCSB Labor Lunch Seminar participants, members of the UCSB Human Capital Working Group, Brian Duncan, Elira Kuka, and other participants at the annual Student Dissertation Workshop at the WEAI, participants at the All-California Labor Economics Conference, participants at the Society of Labor Economists Annual Meeting, as well as seminar participants at Colgate University, Utah State University, UC Irvine Ed Department, and Cal Poly - SLO. All errors are my own. 


\section{Introduction}

Women exit STEM (science, technology, engineering, and math) majors at much higher rates than men, which in part contributes to the gender-wage gap because they miss out on the sizable premiums associated with employment in these fields. ${ }^{1}$ To date, little is known regarding women's decision to drop out of the STEM pipeline in college. Recent research finds that the instructorstudent gender match plays a role in this decision (Carrell et al., 2010; Hoffmann and Oreopoulos, 2009), and that women's responsiveness to grades explains some of the phenomenon as well (Rask and Tiefenthaler, 2008; Ost, 2010), but much remains unexplained. Gaining a better understanding of the factors that cause women to leave STEM fields during college is important for developing policy aimed at bolstering this group's STEM persistence. This paper examines a novel pathway: To what extent does the ability composition of a woman's introductory university STEM course impact STEM persistence?

There are many ways to define classroom composition. In this study it is defined as the share of high ability students in a mandatory introductory STEM lecture, where ability includes effort and motivation, innate ability, and any resources that might aid in academic success. ${ }^{2}$ STEM courses have a distinct environment, they are large and competitive relative to non-STEM courses. Drawing on literature from experimental economics, it has been shown both in the lab as well as in a variety of field settings, that when given the option, women select out of competitive environments at higher rates than men. In a related vein, a National Science Foundation study from the early 2000s, which surveyed roughly 25,000 undergraduate women in STEM, revealed that women are most likely to leave STEM during their first year. The two most cited reasons for leaving were dissatisfaction with grades and the heavy workload, and a distaste for the overall competitive climate (Goodman, 2002). Given what we know about women, a classroom composition that magnifies these features may induce the marginal ones to leave.

\footnotetext{
${ }^{1}$ Paglin and Rufolo (1990); Murnane et al. (1995); Grogger and Eide (1995); Brown and Corcoran (1997); Weinberger (1999); Weinberger (2001); Murnane et al. (2000); Rose and Betts (2004)

${ }^{2}$ Sections 2.1 and 2.2 outline why this measure of average class ability is favorable, and from where exogenous variation in the share of high ability students per lecture arises.
} 
There are several ways in which being assigned to a college lecture with relatively higher ability peers could affect one's outcomes. On one hand, this type of environment could be performance enhancing. Students may benefit directly from higher ability classmates through knowledge spillovers during class, office hours, or out-of-class group study sessions. Additionally, the average class ability can affect the overall standard, and students may be motivated to work harder to keep up with their high achieving peers, consequently earning higher grades.

On the other hand, a high achieving classroom environment may be harmful in more subtle ways by negatively impacting self-perception. The higher the ability of the peers in a classroom, the harder it is to be ranked highly. This may make the environment more competitive. While in many situations competition can improve performance, contest theory suggests that large gaps in skills between competitors can have the perverse effect of reducing effort incentives. Brown (2011) provides empirical evidence for this theoretical prediction by showing that the presence of a superstar in a PGA golf tournament is associated with lower performance by the other competitors. In a classroom setting, marginal students in a competitive environment may see themselves as relatively weak and reduce their effort or even choose to opt out of the competitive climate if possible (i.e., the STEM pipeline).

In a related vein, Niederle and Vesterlund (2007) and Garratt et al. (2013) show that women shy away from competition more than men and that the gender performance gap is exacerbated under competition (Gneezy et al., 2003). Taken together, these findings suggest that women may be more likely to respond negatively to the competitive STEM climate compared to men.

In addition to the sparse literature on women's STEM persistence, there exists relatively little research on post-secondary classroom composition effects because isolating the causal impact is difficult. Often students, or more indirectly administrators, influence the student make-up of a classroom. Several studies at the elementary school level, which for the most part rely on data from the large scale randomized experiment Project STAR, find a positive relationship between average classmate ability and achievement (Whitmore, 2005; Hanushek et al., 2003; Boozer and Cacciola, 2001; Hoxby, 2003). Whether these results extend to a higher education setting, however, 
is an open question.

To date, the most convincing peer effects study in higher education - which estimates small positive effects on freshman grade point average - relies on the random assignment of students from the United States Air Force Academy to squadrons, which are essentially cohorts (Carrell et al., 2009). ${ }^{3}$ This peer group measure is an improvement over previous studies, which define dormmates as the peer group, because squadrons capture a more comprehensive set of students' peer interactions. ${ }^{4}$ None of these studies, however, capture the effects that students within a classroom may have on individual outcomes because dorm-mates and squadron members do not necessarily attend the same classes.

In this study, I leverage administrative data from a large public research institution, University of California Santa Barbara, to estimate the relationship between class ability composition and STEM persistence. This setting is ideal because it circumvents several empirical challenges associated with estimating composition effects. Firstly, the standardized way in which students load into their first STEM course (General Chemistry) - a mandatory prerequisite for nearly all STEM majors at most universities - leaves little room for non-random class enrollment (see Section 2.3). This aspect of the empirical setting allows for the estimation of class ability composition effects free of the usual problem of self-selection.

Secondly, the Transfer Admission Guarantee (TAG) agreement - a program that offers students from California community colleges guaranteed admissions to this university and several other University of California campuses, conditional on meeting certain requirements - generates variation in the ability composition of this introductory STEM course. In particular, the TAG agreement creates stark differences in ability between those students who obtain admissions into the university directly out of high school and those who enter through TAG (see Section 2.1).

\footnotetext{
${ }^{3}$ Similarly, Carrell et al. (2013) run an experiment at the USAFA and show low ability students are harmed by their higher ability squadron members - results which are in-line with my findings. Lyle (2007) uses a similar military dataset (USMA) and cohort approach and finds no evidence of peer effects. A drawback of both of these studies is that students from military institutions likely are not representative of the general university population, especially women.

${ }^{4}$ The following studies use the random assignment of students to dorms to estimate peer effects and find mixed results. Stinebrickner and Stinebrickner (2006) find small positive peer effects on grades for women. Zimmerman (2003) and Sacerdote (2001) find small positive peer effects on students' grades, grade point average, and the take-up of social networks such as fraternities/sororities. Foster (2006) finds no evidence of peer effects.
} 
Thirdly, the introductory STEM course analyzed, General Chemistry, is a required prerequisite for most STEM majors and students cannot circumvent the course by applying Advanced Placement or community college credits, which eliminates another avenue for selection.

Exploiting this quasi-experimental setting, I show that being in a class with higher ability peers reduces the probability that women graduate with a STEM degree and has no significant effect on men. More specifically, a 15\% increase in the number of high ability students in a General Chemistry lecture (one standard deviation) reduces the probability that the average woman graduates with a STEM degree by 3.1 percentage points (6.8\%). As one might expect, I further show that the effect is strongest in the bottom third of the math ability distribution. I rule out grades in the same course as the underlying mechanism by showing that there is a positive relationship for both men and women between peer ability and grades in the STEM gateway course analyzed. Grades in the direct follow-on course, however, are negatively related to the ability composition of the initial course for women, further suggesting the environment of the initial course to be particularly discouraging to women.

The results are informative for at least two reasons. One, they are among the first to show that classmate influences are an important factor in determining students' academic success in higher education, at least for women. ${ }^{5}$ Two, in contrast to most previous work, I focus on STEM major completion rather than grades because STEM completion closely relates to occupation choice, which is an important piece to the gender wage gap story (Murnane et al., 2000; Rose and Betts, 2004).

The remainder of the paper is organized as follows: Section 2 describes the empirical setting. Section 3 presents the econometric specification and results. Section 4 examines possible mechanisms. Section 5 presents concluding remarks.

\footnotetext{
${ }^{5}$ Feld and Zölitz (n.d.) in a recent working paper concurrently show that low ability students are harmed by relatively higher ability peers. Our studies differs in a variety of ways but one key way is that students in their sample are placed in very small classes (15) compared with the average class size of 330 in my sample. As such, the way in which peers affect academic outcomes are quite different across these two settings.
} 


\section{Empirical Setting}

All data in this study are drawn from the University of California Santa Barbara (UCSB) administrative data system. UCSB is a selective, public research institution with a large undergraduate population; enrollment is roughly 23,000 students and the acceptance rate is around $36 \%$. In this analysis, I study the group of UCSB students who are enrolled in the course CHEM1 A - which is the first quarter of the yearlong introductory STEM sequence, General Chemistry - in a fall quarter between 1997 and 2007. ${ }^{6}$ This includes 11 entering cohorts of about 1,100 students each, and tracks them through graduation. At this university, and at the majority of other universities, General Chemistry is the first prerequisite for most STEM majors. ${ }^{7}$ Additionally, students are required to take the course at UCSB; they cannot apply advanced placement credits or test out of the class, which is a strategy often used by students to circumvent introductory math and statistics.

General Chemistry is an ideal setting to study the relationship between STEM persistence and class ability composition because it is a mandatory prerequisite and it has all of the characteristics common to STEM; the course is difficult and competitive. Twenty-five percent of the university's on campus tutoring resources (Campus Learning Assistant Services) go to General Chemistry students. Often the course is considered a STEM major weed-out. Many STEM majors require students to maintain at least a "C" grade point average in the pre-major to gain entry into the major, and because this course is graded on a curve, earning high grades can be difficult. As such, studying the STEM persistence behavior of the group enrolled in CHEM1A captures the students who are most attached to earning a STEM degree.

\subsection{Measure of Average Class Ability}

To construct the class ability composition variable, the data are divided into two distinct groups, on-track students (freshmen) and late-track students (sophomores or higher). Importantly, because

\footnotetext{
${ }^{6}$ This gateway sequence consists of CHEM1 A, CHEM1B and CHEM1C; CHEM1A is offered in the fall, CHEM1B in the winter, and CHEM1C in the spring.

${ }^{7}$ Appendix Table A1 lists the STEM majors that require CHEM1A.
} 
of a key University of California policy, these two groups differ in observable and unobservable ways. On-track students are students who are enrolled in CHEM1A in the fall quarter of their first year at the university. They were admitted into the university directly out of high school and are ontrack to graduate with a STEM degree in four years. Late-track students are upperclassmen taking CHEM1A in a fall quarter other than their freshman year; they are behind schedule to graduate with a STEM degree in four years. Roughly $85 \%$ of the observations in the sample are on-track, totalling 12,230 students. The other $15 \%$ of students $(1,912)$ are late-track. I leverage this variation to construct the main measure of average class ability, the share of on-track students in a section. Note that from here forward I use the term section to refer to what many would consider a lecture or class. Sections are defined as a unique time, instructor, and year.

For the share of on-track students in a section to adequately capture average class ability, the following must hold: (1) late-track students, on average, must differ in ability from on-track students, and (2) there must exist exogenous variation across CHEM1A sections in the share of ontrack students (or alternatively, the share of late-track students). Below I outline the institutional structure which suggests that late-track students are relatively lower ability than on-track students. The institutional structure also provides insight as to how variation in the share of on-track students across sections arises. Finally, I provide evidence from the data supporting conditions (1) and (2).

There are several reasons to believe that late-track CHEM1A students differ on observable (and unobservable) characteristics from on-track students - in particular that they are, on average, lower ability. The late-track group includes three types of students: upperclassmen who switched to a STEM major at some point after entering the university, upperclassmen that needed a year of preparatory courses - remedial math and science - before starting pre-major requirements, and transfer students. In this sample, conditional on being late-track, 621 are transfers and 1,291 are non-transfer upperclassmen. The first type of upperclassmen, although they are behind in their STEM courses, are not necessarily lower ability. The second type, those who come to the university with an inadequate background and take a year of preparatory courses, are, on average, lower ability. 
Transfer students, the third type, typically come from the local city college (or community college). Transferring from a two-year state institution to one of the University of California (UC) campuses is particularly common in California because of the TAG agreement (Transfer Admission Guarantee). This program guarantees admission to one of six UCs if a student completes 30 units with the given minimum grade point average at a public California two-year college. ${ }^{8}$ The TAG agreement was put into place in the early 1980s and the participating UCs include: Santa Barbara, Davis, San Diego, Irvine, Riverside, and Merced.

Central to this paper's empirical approach, TAG and other transfer students are likely financially constrained or did not earn admissions into UCSB directly out of high school. Either way, on average, they have lower high school grades and socioeconomic characteristics relative to the on-track group. To provide additional context on TAG students, in 2014 UC San Diego decided to opt out of the TAG agreement stating that it was squeezing out too many traditional students who had more competitive applications. ${ }^{9}$

Using the share of on-track students in a section as the main measure of average section-mate ability is preferred to other measures typically used in the literature such as the section average of a predetermined characteristic that proxies for ability, i.e. SAT scores. The variable on-track potentially captures a more comprehensive set of observable and unobservable characteristics related to an individual's ability compared with, for example, SAT score. Furthermore, twenty-five percent of the sample's SAT scores are missing since TAG students and other transfers are not required to take the SAT, which, in fact, is the group that generates variation in ability across sections. That said, in a robustness check, I report estimates from the more conventional linear-in-means, leaveme-out approach and find similar results. Results for this robustness check are discussed in Section 3.3.

Finally, the data support the notion that on-track students are on average higher ability than late-track students on observable characteristics. Table 1 reports average predetermined student

\footnotetext{
${ }^{8}$ Grade point average requirements vary by institution, but range from 2.8 to 3.3

${ }^{9}$ Information on UCSD's decision to opt out of the TAG agreement can be found in the San Diego Union-Tribune: http://www.sandiegouniontribune.com/news/2012/may/01/ucsd-ends-community-college-transfer-program/
} 
characteristics and outcomes for each group. Column 1 reports averages for transfer students a subset of late-track students, Column 2 reports averages for all late-track students, Column 3 includes averages for on-track students, and Column 4 reports the difference in means between ontrack and late-track students and indicates if the difference is statistically different from zero. Note that transfer students conditional on reporting an SAT score, on average, have $44 \%$ of a standard deviation lower SAT math score than the on-track group, a characteristic that tends to be a strong predictor of STEM success. Put differently, the average transfer SAT math score is around the 69th percentile on the national scale while the average on-track score is around the 81 st percentile. Moreover, on-track students on average have a higher high school grade point average than nontransfer, late-track students. ${ }^{10}$ Finally, on-track students on average have a much higher predicted grade in the first quarter of General Chemistry ${ }^{11}$, are more likely to graduate in STEM, and their actual grade in CHEM1A is considerably higher.

\subsection{Variation in the Share of On-Track Students Across Sections}

Variation in CHEM1A class composition arises from late-track student enrollment patterns. Latetrack students register for fall classes the previous spring before on-track students, who register in the summer. Based on estimated freshmen fall enrollment, the university holds a share of the CHEM1 A seats in each section for incoming freshmen - the majority of seats are held for freshmen as this is typically a first-year course - and offers the other seats to late-track students. In some cases late-track students fill all of the seats allotted to them in a given section and in other cases they do not. Once late-track students have enrolled, all of the remaining seats are filled with on-track students. ${ }^{12}$

For instance, suppose for simplicity that there are 4 sections of CHEM1A offered in a given

\footnotetext{
${ }^{10}$ Unfortunately, the reported high school grade point average for transfer students is from their previous college (typically Santa Barbara City College) and all other reported high grade point averages are from high school. The former is on a 4 point scale while the latter is on a 4.75 scale to account for Advance Placement courses. As such, the two GPAs are not comparable which is why in Table 1 "High School GPA" is not reported for transfers.

${ }^{11}$ See Section 3.3 for the construction of predicted grade.

${ }^{12}$ Because CHEM1A is a highly demanded class, it is rare for a section not to fill to capacity.
} 
year and each has a maximum enrollment of 100. Further suppose that the university decides to make available 30 percent of the seats (30 seats in this case) in each section for late-track students. If in one of the sections all 30 seats are filled, in the second 25 are filled, and in the third and fourth only 20 and 15 respectively are filled, then variation will arise in the number of late-track students across sections. In the second stage of the process, on-track students fill the remaining seats in each section through a standardized enrollment process which provides assignment to sections that is essentially random; the assignment process is outlined in following section.

Because on-track students are essentially randomly assigned to CHEM1A sections and latetrack students have the ability to selectively enroll, in the analysis I only include those observations that are on-track. The only way in which late-track students enter the analysis is through the ability composition variable (the share of on-track students per section). That said, even though I directly exclude late-tracks from the analysis, if late-track students are enrolling based on characteristics that explain academic outcomes, and those characteristics are also correlated with the share of on-track students in a section, then the casual interpretation of the results will be threatened. In Section 2.3.3, I provide several empirical tests to check for selective enrollment and show that late-track student selection is of little concern.

\subsection{Student Assignment to Lectures}

\subsubsection{Identifying Assumption}

The aim of this study is to understand how the ability composition of a section differentially affects STEM persistence for men and women. As such, a sufficient but not necessary assumption is that pre-treatment characteristics explaining a student's academic achievement are uncorrelated with the quality of classmates in a student's section. Random assignment of students to sections will ensure the validity of this assumption. However, because the goal is to understand how the average class ability differentially effects men and women, in order to interpret the estimated effect as causal, it is only necessary that there is no gender based selection. For example, the causal interpretation of the estimated effect is questionable if high ability women systematically enroll in 
sections with a low share of on-track students and high ability men systematically enroll in sections with a high share of on-track students. In this scenario, it is unclear if the composition estimate is capturing the true effect of ability composition on STEM persistence or if it is reflecting student selection into sections.

To alleviate concerns of student selection and gender based student selection, I rely on UCSB's standardized no-priority enrollment process for freshmen (on-track students), which achieves assignment to sections that is as good as random. While the institutional structure is such that there should be essentially no sorting into sections, I provide multiple randomization tests that support both the stronger assumption of no student selection in general, and the weaker but more relevant assumption of no differential selection by gender.

\subsubsection{Institutional Background - Student Assignment to Sections}

During my sample period, $95 \%$ of all first year students attend a fee-based two-day summer orientation either in June, July or August where they register for their fall quarter courses. ${ }^{13}$ Importantly, there is no priority based registration during or before summer orientation for this group. In each orientation session, a percentage of the total seats available in a given "first year" course are made available to that particular orientation session. This equalizes the probability of enrolling in a particular section across all orientation sessions and eliminates the issue of students who attend earlier orientation dates getting all the "good" classes.

At orientation each student is assigned to a group of 15 students. They are placed into orientation groups by declared major, but groups within major are formed randomly. With this group, students attend seminars about university life, map out a class schedule for the first quarter (and first year) under the guidance of a trained orientation leader for their declared major, and register for their first quarter classes. For instance, students in a pre-Biology major orientation group are advised by their leader to take General Chemistry during their first quarter so that they are on-track to get into the major and ultimately graduate in four years.

\footnotetext{
${ }^{13}$ Each summer 12 freshman orientation dates are offered and students can attend the date of their choice.
} 
The structure of course registration is such that only one student in an orientation group is able to register at a time; each group has one laptop and one leader who facilitates registration. Within each group a registration queue is formed by random draw (i.e. creating registration position 1position 15). The student who draws position 1 registers first. Registration opens at the same time for all groups within an orientation session. According to the Director of Orientation Programs and Parent Services at UCSB, the high demand for CHEM1A, the limited seats, the random registration order, and student's general lack of information about instructors due to the fact that enrollment takes place before they move to campus, makes strategic CHEM1A registration very unlikely. ${ }^{14}$

One avenue for selection that may be a concern, if a student has enough flexibility to manipulate her schedule, is time of day preferences. While there is no evidence that this is happening in a differential fashion - that is, high ability women are no more likely to select into the morning sections than men - all specifications include controls for time of day. Making selection even harder, the Chemistry Department strictly enforces a no switching policy. A student can only switch lectures during the first week of the quarter and he must have a student in his desired lecture replace him in his original one: a one for one switch. ${ }^{15}$

A final concern related to student selection that I cannot directly rule out is the possibility that students who attend summer orientation differ from those who do not. Students who do not attend summer orientation register for their fall classes in mid-September prior to the start of the quarter but after all orientation attendees have registered. On-track student estimates will be biased if students who do not attend summer orientation are non-representative and systematically register for sections based on the ratio of on-track to late-track students. If I could observe CHEM1A registration dates I could test for balance using observed predetermined traits between students who attend summer orientation and those who do not. Since these data are unavailable for my

\footnotetext{
${ }^{14}$ Selective enrollment based on instructor preferences is of little concern since the data come from a time period that, for the most part, predates the online site Rate My Professor. Instructor fixed effects are also included in all regressions.

${ }^{15}$ All information regarding freshman orientation and registration comes from an interview with Kim Equinoa (kim.equinoa@sa.ucsb.edu) who was the director of Orientation Programs and Parent Services at UCSB during the years in which the data for this analysis are from. Information on the Chemistry Department's no switching rule comes from the administrative office within the Chemistry Department.
} 
sample period, I have instead obtained registration data for all freshmen enrolled in CHEM1A in fall 2013. Although these students are not in my main sample, the registration behavior should be similar, as the general structure of freshman registration is the same between the two periods.

For this group of students - all freshmen enrolled in CHEM1 A in fall of 2013 - I observe their CHEM1A registration date and time as well as demographics and CHEM1A instructor characteristics. Ninety percent of this sample attended a summer orientation/registration, slightly lower than the $95 \%$ in the main sample. Comparing the observable characteristics of students who attend orientation and those who do not, underrepresented minorities is the only group who is underrepresented in orientation attendance; 38\% of the orientation attending group are URMs compared to $49 \%$ of the non-orientation attending group. There appears to be no selection into orientation attendance by gender, parent's education level, whether one has a high school GPA in the top half of the distribution for the sample, whether one scores in the top half of the SAT math or SAT verbal distribution for the sample, type of high school one attended, and English language learner status. Most importantly, the data indicate that there is no statistically significant difference in the share of on-track students in a section for those who attend summer orientation and those who do not. Appendix Table A2 reports these results.

\subsubsection{Is Student Assignment to Sections Really Random?}

To formally test whether course assignment is random with respect to student characteristics and average section-mate ability for on-track students, balance tests for this group are reported in Table 2. Each column in this table corresponds to a separate regression where a different predetermined student characteristic is regressed on $\ln O_{\text {itnd }}$ and $F_{i} * \ln O_{\text {itnd }} . \ln O_{\text {itnd }}$ is the $\log$ of the number of on-track students in a section for student $i$ who takes CHEM1A in year $t$ with instructor $n$ at time of day $d . F_{i} * \ln O_{\text {itnd }}$ is that variable interacted with a female indicator. ${ }^{16}$ Year fixed effects are also included as students within a year face the same no-priority registration, but not necessarily across years. Excluded from the test are two sections that have enrollment of less than 100 as they were

\footnotetext{
${ }^{16} \mathrm{An}$ explanation for the log transformation is presented in Section 3.
} 
likely added last minute to meet a larger than expected demand for CHEM1A. Results for the main analysis are robust to the exclusion of these two sections and are presented in Column 2 of Table 6 and Column 2 of Tables 8-11. If selection is present, the coefficient on $\ln O_{\text {itnd }}$ will attain statistical significance. Furthermore, if gender based selection exists, the interaction term $F_{i} * \ln O_{i t n d}$ will be significant. Although the coefficient on $\ln O_{\text {itnd }}$ is statistically different from zero at the $10 \%$ level in three cases, the estimates are essentially zero in magnitude. More importantly for my purposes, there is no evidence of a gender differential in selection across section composition; $F_{i} * \ln O_{i t n d}$ is not statistically different from zero in any of the five cases.

In a related vein, even though late-track students do not directly enter into the analysis, the number of late-track students in a section is used to construct the share of on-track students in a section. As such, to alleviate concerns of selection bias from this group, a balance test for latetrack students is reported in Table 3 and shows no sign that this group is selecting on observable characteristics into sections based on the ability composition of the section. There is some evidence that late-track students with higher grade point averages select morning sections but, importantly for this paper's empirical approach, time of day is uncorrelated with the share of on-track students.

As a second way to empirically test the assumption of random assignment, I employ the resampling technique used by Carrell and West (2008) and Lehmann et al. (1986). I test for student selection into CHEM1A sections by five pre-treatment characteristics: high school grade point average, math SAT score, verbal SAT score, parent is a college graduate, and unrepresented minority status. For each section I calculate the number of on-track students in a section and then randomly draw 10,000 samples of equal size without replacement from the group of all on-track students enrolled in any CHEM1A section in a given year. For each randomly sampled section, I compute the average pre-treatment characteristic (i.e. high school grade point average) and an empirical p-value representing the share of simulated sections with an average pre-treatment characteristic less than the observed average for the given section. If assignment is random, the distribution of empirical p-values will be uniform since any p-value is equally likely to be observed. I obtain 55 p-values, one per year per pre-treatment trait. I test for uniformity of the empirical p-values by 
year by trait using a Kolmogorov-Smirnov one-sample equality of distribution test.

Table 4 Panel A reports the results and shows that for all eleven years and the five pre-treatment characteristics, the null hypothesis of random assignment is not rejected at the five percent level. I repeat the same exercise for the late-track group, reported in Table 4 Panel B, and reject the null hypothesis of random assignment in only two of the 55 cases at the 10 percent level of significance. Recall from Section 2.3 that on-track students and late-track students enroll in CHEM1A at different times and under different rules; which in fact is the very reason that there are differences in average ability across sections. As such it is necessary to perform this simulation for the two groups separately. A simulation where the two groups are considered together will, by construction, result in the rejection of random assignment. In summary, I find very little empirical evidence that students are selectively enrolling into sections by academic ability.

\subsection{Data}

Table 5 presents summary statistics for the main sample, which includes all on-track students. From 1997-2007 there are 46 CHEM1A sections taught by 13 different instructors. The average section size is 329 students. On average, on-track students make up $85 \%$ of each section; the minimum is $71 \%$ and the maximum is $96 \%$. The main outcome of interest is STEM completion, defined as graduating with a STEM major from UCSB within five years. Among entering freshmen who take CHEM1A, the average STEM completion rate is 53\% for men and $45 \%$ for women. Other outcomes used in this analysis are a student's grade in CHEM1A, whether a student takes the direct follow-on course (CHEM1B), and a student's grade in CHEM1B. The average CHEM1A grade for males is a $2.65 \mathrm{GPA}$ (on a 4 point scale) and a 2.49 for women. Of all freshmen who take CHEM1A, $85 \%$ of men and $80 \%$ of women continue on to CHEM1B where the average grade earned in CHEM1B for men and women is 2.59 and 2.58 respectively.

UCSB administrative data also include several socioeconomic measures: race, sex, high school grade point average, SAT math and verbal scores, type of high school (public or private), parents' highest education level, English proficiency and age. Limited information is also available re- 
garding instructors and course times. These include an instructor's sex and a unique instructor identification number, as well as the year, day, and time of the section. These data are linked to students.

\section{Econometric Specification and Results}

The primary specification is the following linear probability model:

$$
G_{\text {itnd }}=\alpha_{1}+\beta_{1} F_{i}+\beta_{2} \ln O_{\text {tnd }}+\beta_{3} F_{i} * \ln O_{\text {tnd }}+\alpha_{2} C_{\text {tnd }}+\alpha_{3} X_{i}+\alpha_{3} M_{\text {tnd }}+\phi_{t}+\rho_{n}+\varepsilon_{\text {itnd }}
$$

The variable $G_{\text {itnd }}$ denotes STEM major completion for an on-track student $i$ who takes CHEM1A in year $t$ with instructor $n$ at time of day $d$; tnd uniquely identifies an individual section in a specific year. $F$ is a female indicator variable and $O_{t n d}$ is the number of on-track students in a specific section. The log transformation allows one to interpret the on-track estimate as a percent change and takes into account that a one student change is proportionately larger from a small base. ${ }^{17}$ The coefficient $\beta_{2}$ captures the effect of the number of on-track students per section on the outcome for men. The coefficient on the interaction term $F_{i} * \ln O_{t n d}$ is the differential effect of the number of on-track students per section for women. Thus, for women the percentage point change in STEM graduation associated with a percent increase in the number of on-track students is $\beta_{2}+\beta_{3}$. $C_{\text {tnd }}$ controls for several class level characteristics: the log of the total number of students enrolled in a given section and the percent female. The section size variable includes the log of the total number of on-track and late-track students enrolled in a given section. $X_{i}$ is a vector of student background characteristics including: race, if a student went to public high school, if English is the only language spoken in the home, the highest level of education attainment of the parent with the highest level of education, high school grade point average, SAT math and verbal scores, age, and the student's intended major at entry (hard sciences, Biology/Environmental Science, Social Sciences, Humanities/Arts/interdiciplinary, and undeclared). $M$ indicates that the section took

\footnotetext{
${ }^{17}$ In an alternative specification, I use percent of on-track students in a lecture as the measure of class composition and obtain similar results, see Section 3.3.
} 
place in the morning (starting at 8 a.m. or 9 a.m.). Year fixed effects $\left(\phi_{t}\right)$ are included to control flexibly for time trends in STEM completion. Since many instructors appear repeatedly, I include instructor fixed effects $\left(\rho_{n}\right)$ to control for time-invariant instructor differences. All standard errors are clustered at the section level (instructor/year/time of day).

Fewer than $1 \%$ of on-track observations are missing SAT scores, and $0.5 \%$ of on-track observations are missing high school grade point average. To deal with these missing values, I impute values using the average of those with a reported value by sex. For example, for a female missing the SAT math score, I fill in with the average SAT value of all female on-track students in the sample. I also include a vector of indicator variables, one for each pretreatment variable, in all regressions which takes on a value of one if the pretreatment variable is missing.

\subsection{Main Results}

Results from the main specification (Equation 1) - which estimates the differential impact of the number of on-track students in a section for men and women - are reported in Table 6. Column 1 of Table 6 reports results for the full sample and shows that increasing the number of on-track students in a class by $15 \%$ reduces the probability that a woman graduates with a STEM major by 3.1 percentage points (see Column 1, panel B). Table A3, a companion table to Table 6, reports the main results with and without various controls. The main effects change very little as covariates and fixed effects are included, providing further reassurance that student selection into sections is not driving the results. Increasing the number of on-track students by $15 \%$ in the average section is equivalent to adding 44 more on-track students to a section with 281 on-track students, which is about one standard deviation. To give context to the magnitude of the results, the average STEM graduation rate for women is $45 \%$ and $53 \%$ for men. Thus, a $15 \%$ increase in the number of ontracks student in a section decreases the STEM graduation rate for an average woman from $45 \%$ to about $42 \%$, which is a decrease of $6.6 \%$. For men, Column 1 suggests that there is no statistically significant relationship between the ability of the students in his CHEM1A section and the rate at which he persists in STEM. 


\subsection{What Does the Estimated Composition Effect Include?}

While the aim of this analysis is to understand the total effect of a student's section-mates on that student's STEM outcomes, it is worth noting that in principle the total estimated composition effect can embody three distinct effects: correlated effects, endogenous peer effects, and exogenous peer effects (also known as contextual effects) (Manski, 1993). Correlated effects are present when groups of individuals form based on common characteristics - i.e. ability - and, as a result, behave similarly. This is often caused by students self-selecting into a group. Because, in my setting, students load into sections in an as good as random way, the composition estimates are free of correlated effects.

Endogenous peer influence is often described as the "reflection" problem and refers to the empirical challenge of disentangle the effect of a group on an individual's outcome from the effect that an individual has on the group (Moffitt et al., 2001; Sacerdote, 2001). The two are often determined simultaneously as peer interactions are reciprocal in nature. In an attempt to mitigate reflection, I follow a strategy common to this literature; I control for previous peer achievement (Carrell et al., 2009, 2013; Hanushek et al., 2003).

Lastly, contextual effects capture the effect of a student's classmate's predetermined characterises - high school grade point average, SAT scores etc. - on her own outcomes. It is often the goal of the empiricist to isolate the exogenous effect net of the other two effects, but in this study I am interested in estimating the total composition effect. The presence of an endogenous effect does not undermine the empirical findings. ${ }^{18}$

A final concern is that the results are an artifact of a mechanical relationship between the measure of own and peer ability as described in Angrist (2014). A mechanical relationship stems from measurement error and is distinct from selection bias. In this study, however, because I show assignment of students to sections is as good as random, any bias stemming from measurement error will only attenuate the composition estimates. That is, the estimated negative composition

\footnotetext{
${ }^{18}$ If one believes that endogenous effects are present, and assuming that both the exogenous and endogenous effects are negative, my estimate of the "total effect" will overstate the exogenous effect. That is, the estimate will be inflated by a social multiplier, and be more negative than the true exogenous effect.
} 
effect is an upper bound; the true effect may be even more negative (Feld and Zölitz, n.d.).

\subsection{Sensitively and Heterogeneity Analysis}

There are two sections in the sample that are substantially smaller than the rest having fewer than 100 students. Although the simulation presented in Table 4 reveals that students are not sorting into sections based on observable characteristics, investigating these small sections is warranted. More than likely these sections were added last minute to meet a larger than expected CHEM1A demand, however, the data do not allow one to observe added sections. ${ }^{19}$

If these small sections are added, the on-track students assigned to them have the greatest potential to be non-representative. For instance, the small percent of on-track students who do not attend a summer orientation session and also enroll in CHEM1A (which is on average 5\% percent of an incoming freshman class) are most likely assigned to an add-on lecture during the first week of school. One would expect this non-summer orientation attending group of students to be less advantaged, thereby dampening the estimated on-track student effect found in the main specification. ${ }^{20}$

Column 2 of Table 6 reports the estimates for the subsample which excludes sections with fewer than 100 students; variation in percent on-track student per section ranges from 75 to $96 \%{ }^{21}$ Results for this subsample indicate that small sections are not driving the main findings. In fact, the magnitude of the estimated on-track student effects for women and men are not statistically different from the estimated effects using the whole sample.

Similar results to the main findings are obtained using alternative measures of section ability composition and are reported in Table A4 and Table A5. First, I replace the $\log$ of the number of on-track students in a section with the percent of on-track students. The main difference between

\footnotetext{
${ }^{19}$ Although many years the Chemistry Department accurately estimates the demand for CHEM1A, there are cases where they add an additional lecture the week before the fall term begins.

${ }^{20}$ Non-orientation attending students are likely less advantaged because summer orientation is an additional cost. According to UCSB office of Orientation Programs and Parent Services, the most common reason students do not attend orientation is due to summer employment.

${ }^{21} \mathrm{~A}$ balancing test for the subsample is statistically the same as the balancing test for the main sample. This table is available upon request.
} 
these two measures is that percent on-track assumes a constant marginal effect regardless of the base. Although somewhat noisier, the estimated effects for men and women are quite similar in magnitude; the interaction term is just shy of statistical significance at the $10 \%$ level.

Additionally, I construct a measure of section composition which more closely aligns to those found in other peer effects studies, and that will allow me to estimate a standard linear-in-means model. Using the observed predetermined characteristics, I first predict a CHEM1A grade $(\hat{p})$ for each observation in the full sample (on-track and late-track), essentially creating a composite background variable for each individual. I construct a composite variable rather than use a single characteristic, i.e. SAT math, to deal with the fact that many late-track observations are missing values for SAT math. In fact, $75 \%$ of transfer students do not report an SAT score as they are the group gaining admissions through the TAG program. Additionally, using average high school grade point average as a proxy for section ability also poses an issue because transfer student's grade point average is reported on a different scale from all other students. ${ }^{22}$

In order to get a predicted grade for each observation, including those that are missing important pretreatment variables, I impute missing values using the average for their type (on-track/male, on-track/female, late-track/transfer/male, late-track/transfer/female, late-track/non-transfer/male, late-track/non-transfer/female) and also include an indicator for missing variables (i.e. SAT math missing etc.). To deal with differences in grade point average scale, I standardize reported high school grade point average. Once I obtain a predicted grade for each observation, I run the following second stage regression for the sample of on-track students:

$$
G_{\text {itnd }}=\alpha_{1}+\beta_{1} F_{i}+\beta_{2} \overline{\hat{p}_{-i t n d}}+\beta_{3} F_{i} * \overline{\hat{p}_{-i t n d}}+\beta_{4} \hat{p}_{i t n d}+\alpha_{2} C_{\text {tnd }}+\alpha_{3} M_{i}+\phi_{\text {tnd }}+\rho_{n}+\varepsilon_{i t n d}
$$

where $\bar{p}_{- \text {itnd }}$ is the average predicted grade for everyone else in the section including late-track students, $F_{i} * \overline{\hat{p}}_{-i t n d}$ is corresponding interaction term, and $\hat{p}_{\text {itnd }}$ is the predicted grade for individual $i$. The results are similar to the main findings. While in this specification both women and men

\footnotetext{
${ }^{22}$ The "high school" grade point average reported for transfer students is from their previous college, which predominantly is the local city college, and thus may not be comparable to a high school grade point average.
} 
appear to be negatively affected by on-track students, women are still more negatively impacted which is consistent with the main findings of this paper. I also estimate Equation 1 as a probit model rather than a linear probability model and obtain similar results. In a final robustness check, I expand the sample to include late-track and on-track students. These results are presented in Table A6 and are quite similar to those found in the original sample.

Understanding which group of students is driving the main result is important for developing and implementing interventions. Columns 3-5 of Table 6 report results disaggregated by SAT math score. The effect is strongest for women in the bottom third of the SAT math distribution. A $15 \%$ increase in the number of on-track students in a class reduces the probability by 5.7 percentage points that a women in this SAT math group completes college with a degree in STEM, and this effect is statistically different from the estimated effects in the other two SAT categories (Columns 4 and 5). Consistent with the main finding, the men in all subsamples appear to be unaffected by the classroom composition. While it is intuitive that women in the lower part of the math ability distribution are the group most affected by classroom composition since they are the group most at risk of dropping out of STEM, these results oppose the findings in Carrell et al. (2010). They find that the group influenced by STEM interventions are women at the top of the SAT math distribution. In particular, they document that women in the top $25 \%$ of the SAT math distribution with female STEM instructors are more likely to graduate with a STEM major.

One might wonder if the results truly are a gender effect. It is possible that I am capturing an underrepresented minority effect or merely picking up the fact that all students at the bottom end of the SAT math distribution are less likely to graduate with a degree in STEM. Columns 1 and 2 of ?? report results from the specifications outlined in Equations 3 and 4 respectively. These models, which are extensions of Equation 1, include a triple interaction term allowing one to disentangle differences in the on-track student effect across gender and race (Column 1), as well as gender and position in the SAT math distribution (Column 2).

$$
\begin{gathered}
G_{i t n d}=\alpha_{1}+\beta_{1} F_{i}+\beta_{2} \ln O_{t n d}+\beta_{3} U R M_{i}+\beta_{4} F_{i} * U R M_{i}+\beta_{5} \ln O_{t n d} * U R M_{i}+\beta_{6} F_{i} * \ln O_{t n d}+ \\
\beta_{7} F_{i} * U R M_{i} * \ln O_{i}+\alpha_{2} C_{t n d}+\alpha_{3} X_{i}+\alpha_{3} M_{t n d}+\phi_{t}+\rho_{n}+\varepsilon_{i t n d}
\end{gathered}
$$




$$
\begin{gathered}
G_{i t n d}=\alpha_{1}+\beta_{1} F_{i}+\beta_{2} \ln O_{\text {tnd }}+\beta_{3} \text { Low }_{i}+\beta_{4} F_{i} * \text { Low }_{i}+\beta_{5} \ln O_{\text {tnd }} * \text { Low }_{i}+\beta_{6} F_{i} * \ln O_{\text {tnd }}+ \\
\beta_{7} F_{i} * \text { Low }_{i} * \ln O_{i}+\alpha_{2} C_{\text {tnd }}+\alpha_{3} X_{i}+\alpha_{3} M_{\text {tnd }}+\phi_{t}+\rho_{n}+\varepsilon_{\text {itnd }}
\end{gathered}
$$

$U R M_{i}$ denotes whether a student is an underrepresented minority (black, Hispanic, American Indian or Filipino) and Low indicates whether a student falls in the bottom third of the SAT math distribution for the sample in a given year. All other variables are as defined in Section 3. Column 1 shows that all women, regardless of race, have STEM persistence rates that are negatively affected by the number of on-track students in her CHEM1A class. As reported in Column 1 Panel B, URM and non-URM women experience a 3.0 percentage point decline in STEM persistence as a result of an increased number of on-track students. Again, there is no detectable class composition effect for men, URM or non-URM.

Results presented in Table 7 Column 2 further support a gender story. These results show that only women (and not men) in the bottom third of the SAT math distribution for the sample have STEM persistence rates that are affected. In fact, women in this group are 4.0 percentage points less likely to graduate in STEM as a result of a $15 \%$ increase in the number of on-track students in a class. The results for the women are statistically different from zero and statistically different from men in this same SAT math group.

$$
\begin{gathered}
G_{\text {itnd }}=\alpha_{1}+\beta_{1} F_{i}+\beta_{2} \ln O_{\text {tnd }}+\beta_{3} B_{i}+\beta_{4} F_{i} * B_{i}+\beta_{5} \ln O_{\text {tnd }} * B_{i}+\beta_{6} F_{i} * \ln O_{\text {tnd }}+ \\
\beta_{7} F_{i} * \text { Low }_{i} * \ln O_{i}+\alpha_{2} C_{\text {tnd }}+\alpha_{3} X_{i}+\alpha_{3} M_{i}+\phi_{t}+\rho_{i}+\varepsilon_{\text {itnd }}
\end{gathered}
$$

Finally, socioeconomic status may also play a role in one's willingness to leave STEM when placed in a lecture with a higher share of on-track students. I use a similar triple difference specification - as outlined in Equation 4 - and examine the differential effect of on-track concentration on STEM persistence by gender and by parent's level of education. $B_{i}$ indicates if a student has at least one parent with a bachelor's degree. Results presented in Column 3 of Table 6 show that all women, regardless of whether her parent is a college graduate, have an increased probability of exiting STEM. Consistent with all other specifications, the persistence rate for men in all subgroups seems to be statistically unrelated to the composition of the class. Together, these findings provide 
strong evidence that women in the bottom third of the math ability distribution are the group most affected by the ability of their classmates. There is no evidence to support the conjecture that it is merely reflecting minority status, being in the bottom of the ability distribution, or socioeconomic status. $^{23}$

\section{Mechanism Exploration}

These reported findings raise the question: Why are women less likely to graduate with a STEM degree if their first experience with STEM is in a setting with higher ability classmates, and why are men unaffected by this factor? While little is known regarding post-secondary classroom composition effects and student outcomes in general, less is known about the mechanisms at work, and in particular why composition matters more for women. Recall the Goodman Research Group study mentioned in the introduction, which had a goal of identifying, “.. aspects of women's educational experiences that are critical to their retention in engineering." This study finds that women who leave engineering are most likely to leave in their freshman or sophomore year. The top two reasons for leaving are: (1) they are dissatisfied with their grades and/or the heavy workload, and (2) they dislike the overall climate of the major, including the competitive nature and discouraging faculty and peers. Both of these factors may be directly influenced by the class composition.

\subsection{Grades}

First, I investigate grades in the initial course as a possible mechanism. In addition to the study by the Goodman Research Group, several studies in economics find that women are more responsive to grades than men, and as a result exit STEM majors. ${ }^{24}$ If all CHEM1A classes are graded on a similar curve (i.e. 10 percent of the class earns an A grade, 35 percent earns a B grade etc.), then

\footnotetext{
${ }^{23}$ In an additional unreported analysis, I further investigate if the gender composition of the late-track group plays a role in explaining female's stem persistence, and find no conclusive results.

${ }^{24}$ The average grade in STEM courses is much lower than humanities, social sciences, arts and interdisciplinary courses. Rask and Tiefenthaler (2008) and Ost (2010) show that women in STEM are more responsive to grades than men.
} 
students in lectures with more high ability classmates will receive lower grades relative to their counterpart (those in lectures with fewer on-track students). For instance, suppose that there are two CHEM1A lectures with equal enrollment in a given fall quarter and one has more on-track students than the other. Relying on the fact that lectures with more on-track students are overall higher ability (Table 1), then a student receiving a score of $77 \%$ in the lecture with more on-track students will be assigned a lower final letter grade than if she was in a class with fewer on-track students.

To explore this possibility, I use a specification similar to Equation 1 with a student's CHEM1A grade as the outcome. CHEM1A grade is a variable taking on values from 0 to 4 . If grades are the underlying mechanism, students in classes with more on-track peers should receive lower final grades. The results presented in column 1 of Table 8 , however, show no sign of this. In fact, both men and women experience higher grades in CHEM1A as a result of an increase in the number of on-track students in a class. Columns 2-7 further show that this result is robust to a variety of subsamples. It appears that all students - male, female, URM, non-URM, the low SAT math scoring group and high SAT math scoring group - experience a marginal increase in their grade. These results are also robust to the subsample which excludes lectures with fewer than 100 students. Quantile regression results (available upon request) further reveal that a positive effect is detectable at all places in the distribution for both men and women which suggests that the overall grade distribution for classes with a higher share of on-track students is shifted to the right. Moreover, if grades are driving the result, controlling for CHEM1A grade in the main specification (Equation 1) should diminish the composition estimates. Table 9 reports such estimates and shows that the effect remains despite controlling for initial course grade, and the differential effect persists as well.

It is possible that the grade findings are a result of positive peer effects as it has been shown that higher ability peer groups elicit higher individual grades (Stinebrickner and Stinebrickner, 2006; Han and Li, 2009; Zimmerman, 2003; Sacerdote, 2001; Carrell et al., 2009). Given the structure of the data, however, I cannot rule out that the positive grade effect is merely an artifact of instructors 
adjusting their grade scales based on the overall ability of the students. For instance, positive effects will emerge if instructors increase everyone's grade in a class because on-whole they are high achieving; a channel that instructor fixed effects will not capture because this behavior is time-varying.

\subsection{Course Climate}

General Chemistry is competitive and women, when given the option, are more likely to select out of competitive environments (Niederle and Vesterlund, 2007; Garratt et al., 2013). The competitive environment in the introductory chemistry course comes from at least three sources, (1) the course is required for most STEM majors and students are required to keep a "C" average in the introductory sequence to advance to upper division courses, (2) because many STEM majors are graduate school and medical school prerequisites, students are motivated to maintain a high grade point average, and (3) grades are assigned based on a curve. Increasing the share of high ability students therefore increases competition in an already competitive environment.

Additionally, the composition of the class could affect students' self-perception about their immediate and future success in the major. Presumably, all students enter the initial course with an expectation about how they will do. Throughout the course they learn about their relative standing and update beliefs about themselves accordingly. Individuals in sections with relativity higher ability classmates may adjust these believes differently relative to those who are not. For example, Pop-Eleches and Urquiola (2013) show that students who just make it into better high schools receive better exam scores but also report feeling marginalized and relatively weaker compared to students who are placed in classes with lower ability classmates. To the extent that women's self-perception about their future success is more negatively affected by the ability of those around them, it could explain their much lower retention rate. Along these lines, if women are more risk averse, then the marginal women may switch to majors where they perceive having a higher chance of "making it" while marginal men gamble by staying in STEM. Consistent with this idea, Kuziemko et al. (2014) show that men are more likely to gamble to avoid low rank whereas women 
accept it. ${ }^{25}$

There are many reasons to believe that women might be turned off by the climate in STEM while men are not. As a result, marginal women may become discouraged and either exert lower effort or quit STEM altogether. Some evidence supporting the idea that women become discouraged is in the take-up of the direct follow-on course, CHEM1B. Twenty percent of women exit the general chemistry sequence after the initial course compared to $15 \%$ of men and some of this is attributable to the composition of the introductory course. Table 10 reports results for a linear probability model similar to Equation 1 where the outcome is equal to one if a student takes CHEM1B and zero otherwise. This table shows that women's and men's CHEM1B take-up is unrelated to CHEM1A classroom composition for the whole sample (Column 1), but when broken out by SAT math subgroups the results indicate that CHEM1B take-up for women in the bottom third of the SAT math distribution - which is the group with STEM major completion most affected by classroom composition - is negatively related to the number of on-track students in a class (Column 5). The estimated effect is statistically different from zero and statistically different from the effect for men in this same group, but due to the noisy estimates in the other subsamples, I cannot reject that the effect for women is the same as the estimated effects for women from the other SAT math groups (the middle third and the top third). These results are robust to a specification that controls for CHEM1A grade as well.

Next, I estimate a small negative relationship between number of on-track students and CHEM1B grade for women and find no statistically significant effect for men (Table 11, Column 1). An increase in the number of on-track students of $15 \%$ is related to a reduction in a woman's CHEM1B grade of 0.08 grade points which is $27 \%$ of a letter grade. This estimate should be considered understated as some students - particularly those near the bottom of the ability distribution - have already exited the pipeline as a result of the introductory class composition and are no longer in the sample (see Table 10). It is very likely that this follow-on grade finding reflects a student's overall discouraged feeling - i.e. lack of effort - particularly if she feels marginalized in the introductory

\footnotetext{
${ }^{25}$ Although data for this study comes from the laboratory and manipulates an individual's rank in the wealth distribution, it is reasonable that the detected behavioral response extends to a classroom ability distribution.
} 
course. It is also possible that learning or mastering the fundamental skills needed to successfully complete a STEM degree is lower for women in introductory classes with higher quality students. The latter explanation, however, is not supported by the data as I find a positive relationship between the ability composition in a classroom and CHEM1A grade for women.

Finally, I show that women are responding to the composition of their introductory course by switching into majors that are relatively less quantitative. ${ }^{26}$ Table 12 , Column 1 reports that increasing the number of on-track students in a class by $15 \%$ leads to a 3.2 percentage point increase in the probability that a woman graduates with a humanities, social sciences, art, or interdisciplinary major. ${ }^{27}$ This table shows that women are still graduating (as shown in Column 2) but on average they are graduating in majors that are lower paying, less quantitative, and arguably less competitive.

Although I can not directly point to the channel by which high ability classmates adversely affect women's STEM retention, I can rule out that the effect is operating directly through grades in the initial course. There are, however, various other ways in which the climate may discourage women that are consistent with my findings including competition, self-perception, and risk aversion. It may be the case that women who randomly are placed in classes with relatively higher ability peers, work hard to keep up with their classmates in the initial course (or the instructor shifts the grade distribution and it appears that they are earning higher grades in that course), but decide that they cannot endure that environment for four more years and give-up on their STEM pursuit. Consistent with this story, I show that in response to the share of high ability classmates in their initial course, many women exit the STEM pipeline either directly after their initial course or at some other point in favor of majors that arguably have a less competitive environment.

\footnotetext{
${ }^{26}$ Appendix Table A7 outlines by sex the percent of students in each major category at entry and at graduation.

${ }^{27}$ I get similar results when I exclude Economics (Econ, Econ-Math, and Econ-Accounting) and Psychology from this group.
} 


\section{Discussion and Conclusion}

It has been well documented that women are less likely than men to persist in STEM majors and careers. This study targets a unique group of students, those taking General Chemistry in their first quarter of college, to better understand how one's first collegiate experience in STEM explains STEM major graduation rates. Relying on data containing roughly 12,000 first year university students from 11 entering cohorts between 1997-2007, I estimate the causal relationship between the ability of one's classmates in a required STEM major course and a student's STEM major completion.

In summary, I find that women who are assigned to a STEM lecture with higher ability peers at the start of their university career are less likely to persist in STEM while men's persistence behavior is unaffected. I have ruled out the possibility that women earn lower grades in classes with higher ability classmates and as such are less likely to persist. Alternatively, I find evidence consistent with the hypothesis that women's decision to exit is a response to the climate created in classes with higher ability peers. In fact, given my results, it is not implausible that marginal women are deterred by the climate, become discouraged, and eventually exit to majors with a less competitive environment. I show that at least some of these women leave the STEM pipeline immediately after the initial General Chemistry course as a result of the ability of their classmates.

This study is the first to provide an analysis of the relationship between classroom composition and STEM degree completion in higher education, and to document the differential response by gender. It is also among the first to examine the effects of classroom composition in higher education. Broadly, the results from this study suggests that women's longer run STEM persistence is affected by her experience in the gateway course, and, in particular, that the classroom ability composition plays a crucial role. By identifying this new channel through which women opt out of STEM, the estimates presented in this paper provide potentially important information to policymakers attempting to bolster the participation of women in STEM fields. 


\section{References}

Abdulkadiroglu, Atila, Joshua D Angrist, and Parag A Pathak, "The Elite Illusion: Achievement Effects at Boston and New York Exam Schools," Technical Report, Econometrica 2014.

Angrist, Joshua D, “The Perils of Peer Effects,” Labour Economics, 2014, 30, 98-108.

Bertrand, Marianne, Esther Duflo, and Sendhil Mullainathan, "How Much Should we Trust Differences-in-Differences Estimates?,' The Quarterly Journal of Economics, 2004, 119 (1), 249-275.

Boozer, Michael and Stephen E Cacciola, 'Inside the'Black Box' of Project STAR: Estimation of Peer Effects using Experimental Data," Yale Economic Growth Center Discussion Paper, 2001, (832).

Brown, Charles and Mary Corcoran, "Sex-Based Differences in School Content and the MaleFemale Wage Gap," Journal of Labor Economics, 1997, 15 (3), 431-65.

Brown, Jennifer, "Quitters Never Win: The (adverse) Incentive Effects of Competing with Superstars," Journal of Political Economy, 2011, 119 (5), 982-1013.

Carrell, Scott E and Bruce Sacerdote, "Late Interventions Matter Too: The Case of College Coaching in New Hampshire," Technical Report, National Bureau of Economic Research 2013.

_ and James E West, "Does Professor Quality Matter? Evidence from Random Assignment of Students to Professors," Technical Report 2008.

_, Bruce I Sacerdote, and James E West, "From Natural Variation to Optimal Policy? The Importance of Endogenous Peer Group Formation," Econometrica, 2013, 81 (3), 855-882.

_ , Marianne E Page, and James E West, "Sex and Science: How Professor Gender Perpetuates the Gender Gap," The Quarterly Journal of Economics, 2010, 125 (3), 1101-1144.

_ , Richard L Fullerton, and James E West, "Does Your Cohort Matter? Measuring Peer Effects in College Achievement," Journal of Labor Economics, 2009, 27 (3), 439-464.

Chetty, Raj, John N Friedman, Nathaniel Hilger, Emmanuel Saez, Diane Whitmore Schanzenbach, and Danny Yagan, "How Does your Kindergarten Classroom Affect Your Earnings? Evidence from Project STAR,” The Quarterly Journal of Economics, 2011, 126 (4), 1593-1660.

Clark, Damon, "Selective Schools and Academic Achievement," The B.E. Journal of Economic Analysis \& Policy, 2010, 10 (1).

Dobbie, Will and Roland G Fryer Jr, "Exam high schools and Academic Achievement: Evidence from New York City," Technical Report, National Bureau of Economic Research 2011.

Duflo, Esther, Pascaline Dupas, and Michael Kremer, "Peer Effects, Teacher Incentives, and the Impact of Tracking: Evidence from a Randomized Evaluation in Kenya," Technical Report, American Economic Review 2011. 
Feld, Jan and Ulf Zölitz, "Understanding Peer Effects: On the Nature, Estimation and Channels of Peer Effects," IZA Discussion Paper.

Foster, Gigi, "It's Not your Peers, and it's Not your Friends: Some Progress Toward Understanding the Educational Peer Effect Mechanism," Journal of Public Economics, 2006, 90 (8), 14551475 .

Garratt, Rodney J, Catherine Weinberger, and Nick Johnson, "The State Street Mile: Age and Gender Differences in Competition Aversion in the Field," Economic Inquiry, 2013, 51 (1), 806-815.

Gneezy, Uri, Muriel Niederle, and Aldo Rustichini, "Performance in Competitive Environments: Gender Differences," The Quarterly Journal of Economics, 2003, 118 (3), 1049-1074.

Goodman, Irene F., "Final Report of the Women's Experience in College Engineering (WECE) Project," Online Submission, 2002.

Grogger, Jeff and Eric Eide, "Changes in College Skills and the Rise in the College Wage Premium," Journal of Human Resources, 1995, pp. 280-310.

Han, Li and Tao Li, "The Gender Difference of Peer Influence in Higher Education," Economics of Education Review, 2009, 28 (1), 129-134.

Hanushek, Eric A, John F Kain, Jacob M Markman, and Steven G Rivkin, "Does Peer Ability Affect Student Achievement?," Journal of Applied Econometrics, 2003, 18 (5), 527-544.

Hoekstra, Mark, "The Effect of Attending the Flagship State University on Earnings: A Discontinuity-Based Approach," The Review of Economics and Statistics, 2009, 91 (4), 717724.

Hoffmann, Florian and Philip Oreopoulos, "A Professor Like Me the Influence of Instructor Gender on College Achievement," Journal of Human Resources, 2009, 44 (2), 479-494.

Hoxby, Caroline, "The Power of Peers: How Does the Makeup of a Classroom Influence Achievement," Technical Report, Education Next 2003.

Jackson, C Kirabo, "Do Students Benefit from Attending Better Schools? Evidence from Rulebased Student Assignments in Trinidad and Tobago," The Economic Journal, 2010, 120 (549), $1399-1429$.

Kremer, Michael and Dan Levy, "Peer Effects and Alcohol Use Among College Students," The Journal of Economic Perspectives, 2008, 22 (3), 189.

Krueger, Alan B and Diane M Whitmore, Would Smaller Classes Help Close the Black-White Achievement Gap? number 451, Industrial Relations Section, Princeton University, 2001.

Kuziemko, Ilyana, Ryan W Buell, Taly Reich, and Michael I Norton, "Last-place Aversion: Evidence and Redistributive Implications," The Quarterly Journal of Economics, 2014, 129 (1), 105-149. 
Lehmann, Erich Leo, Joseph P Romano, and George Casella, Testing Statistical Hypotheses, Vol. 150, Wiley New York et al., 1986.

Lyle, David S, "Estimating and Interpreting Peer and Role Model Effects from Randomly Assigned Social Groups at West Point," The Review of Economics and Statistics, 2007, 89 (2), 289-299.

Manski, Charles F, "Identification of Endogenous Social Effects: The Reflection Problem," The Review of Economic Studies, 1993, 60 (3), 531-542.

Moffitt, Robert A et al., "Policy Interventions, Low-level Equilibria, and Social Interactions," Social Dynamics, 2001, 4, 45-82.

Murnane, R.J., J.B. Willett, and F. Levy, "The Growing Importance of Cognitive Skills in Wage Determination," Technical Report, National Bureau of Economic Research 1995.

_, _, Y. Duhaldeborde, and J.H. Tyler, "How Important are the Cognitive Skills of Teenagers in Predicting Subsequent Earnings," Journal of Policy Analysis and Management, 2000, 19 (4), 547-568.

Niederle, Muriel and Lise Vesterlund, "Do Women Shy Away from Competition? Do Men Compete Too Much?," The Quarterly Journal of Economics, 2007, 122, 1067-1101.

Ost, Ben, "The Role of Peers and Grades in Determining Major Persistence in the Sciences," Economics of Education Review, 2010, 29 (6), 923-934.

Paglin, M. and A.M. Rufolo, "Heterogeneous Human Capital, Occupational Choice, and MaleFemale Earnings Differences," Journal of Labor Economics, 1990, pp. 123-144.

Park, Albert, Xinzheng Shi, Chang-Tai Hsieh, and Xuehui An, "Does School Quality Matter?: Evidence from a Natural Experiment in Rural China," Preliminary Draft, 2010.

Pop-Eleches, Cristian and Miguel Urquiola, "Going to a Better School: Effects and Behavioral Responses," Technical Report, American Economic Review 2013.

Rask, Kevin and Jill Tiefenthaler, "The Role of Grade Sensitivity in Explaining the Gender Imbalance in Undergraduate Economics," Economics of Education Review, 2008, 27 (6), 676687.

Rose, H. and J.R. Betts, "The Effect of High School Courses on Earnings," Review of Economics and Statistics, 2004, 86 (2), 497-513.

Rubinstein, Yona and Sheetal Sekhri, "Do Public Colleges in Developing Countries Provide Better Education than Private Ones? Evidence from General Education Sector in India. CEE DP 130.," Centre for the Economics of Education (NJ1), 2011.

Saavedra, Juan Esteban, “The Learning and Early Labor Market Effects of College Quality: A Regression Discontinuity Analysis," Investigaciones del ICFES, 2009. 
Sacerdote, Bruce I, "Peer Effects with Random Assignment: Results for Dartmouth Roommates," The Quarterly Journal of Economics, 2001, 116 (2), 681-704.

Stinebrickner, Ralph and Todd R Stinebrickner, "What Can Be Learned About Peer Effects Using College Roommates? Evidence from New Survey Data and Students from Disadvantaged Backgrounds," Journal of Public Economics, 2006, 90 (8), 1435-1454.

Weinberger, Catherine J, "Mathematical College Majors and the Gender Gap in Wages," Industrial Relations: A Journal of Economy and Society, 1999, 38 (3), 407-413.

Weinberger, C.J., "Is Teaching More Girls More Math the Key to Higher Wages?," Squaring Up: Policy Strategies to Raise Womens Income in the US, 2001.

Whitmore, Diane, "Resource and Peer Impacts on Girls' Academic Achievement: Evidence from a Randomized Experiment," American Economic Review, 2005, pp. 199-203.

Wozniak, David, William T Harbaugh, and Ulrich Mayr, "The Menstrual Cycle and Performance Feedback Alter Gender Differences in Competitive Choices," Journal of Labor Economics, 2014.

Zimmerman, David J, "Peer Effects in Academic Outcomes: Evidence from a Natural Experiment," Review of Economics and Statistics, 2003, 85 (1), 9-23. 
Table 1: On-Tracks are Relatively Higher Ability than Late-Tracks

\begin{tabular}{|c|c|c|c|c|}
\hline & $\frac{\text { Transfers }}{(1)}$ & $\frac{\text { Late-Track }}{(2)}$ & $\frac{\text { On-Track }}{(3)}$ & $\frac{\text { Diff. (3) }-(2)}{(4)}$ \\
\hline \multicolumn{5}{|l|}{ Predetermined Characteristics } \\
\hline Women & $\begin{array}{c}0.46 \\
(0.50)\end{array}$ & $\begin{array}{c}0.52 \\
(0.50)\end{array}$ & $\begin{array}{c}0.49 \\
(0.50)\end{array}$ & $\begin{array}{l}-.03 * * \\
(0.01)\end{array}$ \\
\hline URM (underrepresented minority) & $\begin{array}{c}0.33 \\
(0.47)\end{array}$ & $\begin{array}{c}0.32 \\
(0.47)\end{array}$ & $\begin{array}{c}0.32 \\
(0.47)\end{array}$ & $\begin{array}{c}0.00 \\
(0.01)\end{array}$ \\
\hline Predicted CHEM1A grade & $\begin{array}{c}2.10 \\
(0.62)\end{array}$ & $\begin{array}{c}3.33 \\
(0.01)\end{array}$ & $\begin{array}{c}3.56 \\
(0.00)\end{array}$ & $\begin{array}{l}0.22 * * * \\
(0.01)\end{array}$ \\
\hline High School G.P.A & - & $\begin{array}{c}3.68 \\
(0.35)\end{array}$ & $\begin{array}{c}3.75 \\
(0.32)\end{array}$ & $\begin{array}{l}0.06 * * * \\
(0.01)\end{array}$ \\
\hline SAT math score & $\begin{array}{l}577.67 \\
(81.22)\end{array}$ & $\begin{array}{l}604.34 \\
(80.95)\end{array}$ & $\begin{array}{l}612.74 \\
(80.84)\end{array}$ & $\begin{array}{c}8.4 * * \\
(2.25)\end{array}$ \\
\hline SAT verbal score & $\begin{array}{l}544.40 \\
(84.04)\end{array}$ & $\begin{array}{l}575.91 \\
(83.66)\end{array}$ & $\begin{array}{l}569.58 \\
(84.59)\end{array}$ & $\begin{array}{l}-6.33 * * \\
(2.33)\end{array}$ \\
\hline Public high school & $\begin{array}{c}0.94 \\
(0.24)\end{array}$ & $\begin{array}{c}0.86 \\
(0.35)\end{array}$ & $\begin{array}{c}0.85 \\
(0.36)\end{array}$ & $\begin{array}{c}-0.01 \\
(0.01)\end{array}$ \\
\hline English spoken in home & $\begin{array}{c}0.67 \\
(0.47)\end{array}$ & $\begin{array}{c}0.69 \\
(0.46)\end{array}$ & $\begin{array}{c}0.67 \\
(0.47)\end{array}$ & $\begin{array}{c}-0.02 \\
(0.01)\end{array}$ \\
\hline No parent college grad. & $\begin{array}{c}0.38 \\
(0.48)\end{array}$ & $\begin{array}{c}0.29 \\
(0.46)\end{array}$ & $\begin{array}{c}0.33 \\
(0.47)\end{array}$ & $\begin{array}{l}0.04 * * \\
(0.01)\end{array}$ \\
\hline \multicolumn{5}{|l|}{ Outcomes } \\
\hline Graduate with STEM major & $\begin{array}{c}0.45 \\
(0.50)\end{array}$ & $\begin{array}{c}0.44 \\
(0.50)\end{array}$ & $\begin{array}{c}0.49 \\
(0.50)\end{array}$ & $\begin{array}{l}0.05^{* *} \\
(0.01)\end{array}$ \\
\hline Graduate & $\begin{array}{c}0.76 \\
(0.43)\end{array}$ & $\begin{array}{c}0.82 \\
(0.38)\end{array}$ & $\begin{array}{c}0.81 \\
(0.39)\end{array}$ & $\begin{array}{c}-0.01 \\
(0.01)\end{array}$ \\
\hline CHEM1A grade & $\begin{array}{c}2.05 \\
(1.16)\end{array}$ & $\begin{array}{c}2.26 \\
(1.11)\end{array}$ & $\begin{array}{c}2.57 \\
(0.93)\end{array}$ & $\begin{array}{l}0.31 * * \\
(0.03)\end{array}$ \\
\hline Took follow-on (CHEM1B) & $\begin{array}{l}0.65 \\
(0.48)\end{array}$ & $\begin{array}{c}0.63 \\
(0.48)\end{array}$ & $\begin{array}{c}0.82 \\
(0.38)\end{array}$ & $\begin{array}{c}0.19 * * \\
(0.01)\end{array}$ \\
\hline Grade in follow-on (CHEM1B) & $\begin{array}{c}2.31 \\
(0.96)\end{array}$ & $\begin{array}{c}2.53 \\
(0.97)\end{array}$ & $\begin{array}{c}2.58 \\
(0.87)\end{array}$ & $\begin{array}{c}0.05 \\
(0.03)\end{array}$ \\
\hline Observations & 621 & 1,935 & 12,230 & \\
\hline
\end{tabular}

Notes: On-track students are enrolled in the first quarter of General Chemistry (CHEM1A) in the fall quarter of their freshman year at UCSB from 1997 to 2007. Late-track students are enrolled in CHEM1A during this time frame but are taking the course as an upperclassman or transfer student. URM stands for underrepresented minorities and includes all race categories except white, Asian and Indian. Note that Only 159 of the 621 transfers report SAT scores. High school GPA is not reported for transfers because the data only contain their previous college GPA and not their high school GPA. Level of significance is indicated as follows: $* * \mathrm{p}<0.01, * \mathrm{p}<0.05,+\mathrm{p}<0.1$. Standard deviations are in parentheses. 
Table 2: Are On-Track Students Selectively Enrolling Based on Ability Composition?

\begin{tabular}{|c|c|c|c|c|c|}
\hline & $\frac{\text { URM }}{(1)}$ & $\frac{\text { SAT Math }}{(2)}$ & $\frac{\text { SAT Verbal }}{(3)}$ & $\frac{\text { H.S. GPA }}{(4)}$ & $\frac{\text { Parent is College Grad }}{(5)}$ \\
\hline \multicolumn{6}{|l|}{ Panel A: Point Estimates } \\
\hline $\operatorname{Ln}($ no. of on-track $)$ & $\begin{array}{l}-0.119 \\
(0.059)\end{array}$ & $\begin{array}{c}7.372 \\
(8.062)\end{array}$ & $\begin{array}{c}19.740 \\
(12.210)\end{array}$ & $\begin{array}{c}0.063 \\
(0.030)\end{array}$ & $\begin{array}{c}0.084 \\
(0.073)\end{array}$ \\
\hline $\operatorname{Ln}$ (no. of on-track) X Fem. & $\begin{array}{c}0.057 \\
(0.078)\end{array}$ & $\begin{array}{c}5.852 \\
(4.634)\end{array}$ & $\begin{array}{l}-1.788 \\
(5.250)\end{array}$ & $\begin{array}{l}-0.016 \\
(0.036)\end{array}$ & $\begin{array}{c}0.042 \\
(0.075)\end{array}$ \\
\hline \multicolumn{6}{|c|}{$\begin{array}{l}\text { Panel B: Estimated effects in } \\
\% \text {-pts. associated with a } 15 \% \\
\text { increase in no. of on-track }\end{array}$} \\
\hline The differential effect & 0.80 & 0.82 & -0.25 & 0.00 & 0.01 \\
\hline Women & -0.87 & 1.85 & 2.51 & $0.01+$ & 0.02 \\
\hline Men & $-1.70+$ & 1.03 & 2.76 & $0.01+$ & 0.01 \\
\hline Observations & 12,122 & 12,036 & 12,036 & 12,054 & 12,122 \\
\hline
\end{tabular}

Notes: Each column is a separate regression and also includes year fixed effects as well as a female indicator. On-track students are those enrolled in the first quarter of General Chemistry (CHEM1A) in the fall quarter of their freshman year at UCSB between the years 1997 and 2007. This sample excludes two small classes with enrollment less than 100. URM stands for underrepresented minorities and includes all race categories except white, Asian and Indian. Level of significance is indicated as follows: $* * \mathrm{p}<0.01, * \mathrm{p}<0.05,+\mathrm{p}<0.1$. Standard deviations are in parentheses. 
Table 3: Are Late-Track Students Selectively Enrolling Based Ability on Composition?

\begin{tabular}{|c|c|c|c|c|c|}
\hline & $\frac{\text { URM }}{(1)}$ & $\frac{\text { SAT Math }}{(2)}$ & $\frac{\text { SAT Verbal }}{(3)}$ & $\frac{\text { H.S. GPA }}{(4)}$ & $\frac{\text { Parent is College Grad }}{(5)}$ \\
\hline \multicolumn{6}{|l|}{ Panel A: Point Estimates } \\
\hline $\operatorname{Ln}($ no. of on-track $)$ & $\begin{array}{l}-0.097 \\
(0.092)\end{array}$ & $\begin{array}{l}-11.890 \\
(20.700)\end{array}$ & $\begin{array}{c}7.272 \\
(21.680)\end{array}$ & $\begin{array}{c}0.285 \\
(0.223)\end{array}$ & $\begin{array}{r}0.0613 \\
(0.094)\end{array}$ \\
\hline Ln(no. of on-track) X Fem. & $\begin{array}{l}-0.047 \\
(0.125)\end{array}$ & $\begin{array}{c}18.470 \\
(26.220)\end{array}$ & $\begin{array}{c}12.710 \\
(28.850)\end{array}$ & $\begin{array}{c}0.013 \\
(0.104)\end{array}$ & $\begin{array}{c}0.062 \\
(0.278)\end{array}$ \\
\hline \multicolumn{6}{|c|}{$\begin{array}{l}\text { Panel B: Estimated effects in } \\
\% \text {-pts. associated with a } 15 \% \\
\text { increase in no. of on-track }\end{array}$} \\
\hline The differential effect & -0.65 & 2.59 & 1.79 & 0.18 & 0.87 \\
\hline Women & -2.00 & 0.92 & 2.80 & 4.2 & 1.72 \\
\hline Men & -1.35 & -1.66 & 1.02 & 4.0 & 0.86 \\
\hline Observations & 1,902 & 1,416 & 1,416 & 1,863 & 1,902 \\
\hline
\end{tabular}

Notes: Each column is a separate regression and also includes year fixed effects. On-track students are those enrolled in the first quarter of General Chemistry (CHEM1A) in the fall quarter of their freshman year at UCSB between the years 1997 and 2007. This sample excludes two small classes with enrollment less than 100. URM stands for underrepresented minorities and includes all race categories except white, Asian and Indian. Level of significance is indicated as follows: $* * \mathrm{p}<0.01, * \mathrm{p}<0.05 .+\mathrm{p}<0.1$. Standard deviations are in parentheses 
Table 4: Randomization Check for Section Assignment

\begin{tabular}{|c|c|c|c|c|c|c|c|c|c|c|c|}
\hline & 1997 & 1998 & 1999 & 2000 & 2001 & 2002 & 2003 & 2004 & 2005 & 2006 & 2007 \\
\hline \multicolumn{12}{|c|}{ Panel A: On-Track Students } \\
\hline H.S. GPA & & & & & & & & & & & \\
\hline $\begin{array}{l}K \text {-S Test } P \text {-values } \\
\text { SAT Math }\end{array}$ & 0.274 & 0.17 & 0.284 & 0.277 & 0.281 & 0.273 & 0.274 & 0.283 & 0.284 & 0.28 & 0.178 \\
\hline $\begin{array}{l}K \text {-S Test P-values } \\
\text { Sat Verbal }\end{array}$ & 0.273 & 0.166 & 0.287 & 0.272 & 0.277 & 0.266 & 0.28 & 0.286 & 0.28 & 0.266 & 0.176 \\
\hline$K$-S Test P-values & 0.275 & 0.167 & 0.281 & 0.283 & 0.268 & 0.275 & 0.274 & 0.282 & 0.263 & 0.266 & 0.173 \\
\hline $\begin{array}{l}\text { Col. Grad Parent } \\
K \text {-S Test P-values } \\
\text { URM }\end{array}$ & 0.281 & 0.174 & 0.27 & 0.284 & 0.274 & 0.277 & 0.283 & 0.279 & 0.272 & 0.273 & 0.171 \\
\hline$K$-S Test P-values & 0.266 & 0.177 & 0.278 & 0.275 & 0.273 & 0.271 & 0.278 & 0.284 & 0.274 & 0.277 & 0.165 \\
\hline $\begin{array}{l}\text { Panel B: Late-Tra } \\
\text { H.S. GPA }\end{array}$ & & & & & & & & & & & \\
\hline $\begin{array}{l}K \text {-S Test P-values } \\
\text { SAT Math }\end{array}$ & 0.26 & 0.164 & 0.272 & 0.281 & 0.274 & 0.267 & 0.267 & 0.281 & 0.26 & 0.186 & 0.169 \\
\hline $\begin{array}{l}K \text {-S Test P-values } \\
\text { Sat Verbal }\end{array}$ & 0.273 & 0.175 & 0.209 & 0.23 & 0.244 & 0.244 & 0.25 & 0.131 & 0.259 & 0.273 & 0.10 \\
\hline $\begin{array}{l}K \text {-S Test P-values } \\
\text { Col. Grad Parent }\end{array}$ & 0.218 & 0.171 & 0.269 & 0.233 & 0.216 & 0.192 & 0.256 & 0.193 & 0.208 & 0.053 & 0.146 \\
\hline $\begin{array}{l}K \text {-S Test } P \text {-values } \\
\text { URM }\end{array}$ & 0.287 & 0.174 & 0.29 & 0.271 & 0.296 & 0.285 & 0.266 & 0.273 & 0.27 & 0.288 & 0.16 \\
\hline$K$-S Test P-values & 0.272 & 0.172 & 0.283 & 0.301 & 0.275 & 0.271 & 0.274 & 0.278 & 0.273 & 0.285 & 0.168 \\
\hline
\end{tabular}


Table 5: Summary Statistics (sample includes on-tracks only)

\begin{tabular}{|c|c|c|}
\hline & $\frac{\text { Women }}{(1)}$ & $\frac{\text { Men }}{(2)}$ \\
\hline \multicolumn{3}{|l|}{ Classroom Characteristics } \\
\hline$\%$ on-track in a lecture & $\begin{array}{l}0.85 \\
(0.05)\end{array}$ & $\begin{array}{c}0.85 \\
(0.05)\end{array}$ \\
\hline CHEM1A lecture size & $\begin{array}{l}329.37 \\
(46.73)\end{array}$ & $\begin{array}{r}328.53 \\
(47.37)\end{array}$ \\
\hline $\begin{array}{l}\text { Student Background Characteristics } \\
\text { URM (underrepresented minority) }\end{array}$ & $\begin{array}{c}0.34 \\
(0.47)\end{array}$ & $\begin{array}{c}0.31 \\
(0.46)\end{array}$ \\
\hline High school grade point average & $\begin{array}{c}3.80 \\
(0.31)\end{array}$ & $\begin{array}{c}3.70 \\
(0.33)\end{array}$ \\
\hline SAT math score & $\begin{array}{l}587.59 \\
(78.16)\end{array}$ & $\begin{array}{r}636.41 \\
(75.49)\end{array}$ \\
\hline SAT verbal score & $\begin{array}{l}564.88 \\
(82.63)\end{array}$ & $\begin{array}{r}573.97 \\
(85.60)\end{array}$ \\
\hline Attended public high school & $\begin{array}{c}0.86 \\
(0.35)\end{array}$ & $\begin{array}{c}0.84 \\
(0.37)\end{array}$ \\
\hline English is only language spoken in home & $\begin{array}{c}0.69 \\
(0.46)\end{array}$ & $\begin{array}{c}0.65 \\
(0.48)\end{array}$ \\
\hline No parent graduated from college & $\begin{array}{c}0.36 \\
(0.48)\end{array}$ & $\begin{array}{c}0.29 \\
(0.46)\end{array}$ \\
\hline \multicolumn{3}{|l|}{ Outcomes } \\
\hline Graduate with STEM major & $\begin{array}{c}0.45 \\
(0.50)\end{array}$ & $\begin{array}{c}0.53 \\
(0.50)\end{array}$ \\
\hline Graduate & $\begin{array}{c}0.82 \\
(0.39)\end{array}$ & $\begin{array}{c}0.80 \\
(0.40)\end{array}$ \\
\hline CHEM1A grade & $\begin{array}{c}2.49 \\
(0.95)\end{array}$ & $\begin{array}{c}2.65 \\
(0.91)\end{array}$ \\
\hline Took follow-on course (CHEM1B) & $\begin{array}{c}0.80 \\
(0.40)\end{array}$ & $\begin{array}{c}0.85 \\
(0.36)\end{array}$ \\
\hline Grade in follow-on course (CHEM1B) & $\begin{array}{c}2.58 \\
(0.87)\end{array}$ & $\begin{array}{c}2.59 \\
(0.87)\end{array}$ \\
\hline Observations & 5,942 & 6,288 \\
\hline
\end{tabular}

Notes: The sample includes only on-track students, those enrolled in the first quarter of General Chemistry (CHEM1A) in the fall quarter of their freshman year at UCSB between the years 1997 and 2007. URM stands for underrepresented minorities and includes all race categories except white, Asian and Indian. 
Table 6: The Effect of the Number of On-Track Students on STEM Major Completion

\begin{tabular}{|c|c|c|c|c|c|}
\hline & $\frac{\text { Full Sample }}{(1)}$ & $\frac{\text { Lectures }>100}{(2)}$ & $\frac{\text { Bottom 1/3 SAT Math }}{(3)}$ & $\frac{\text { Middle 1/3 SAT Math }}{(4)}$ & $\frac{\text { Top 1/3 SAT Math }}{(5)}$ \\
\hline \multicolumn{6}{|l|}{ Panel A: Point Estimates } \\
\hline $\operatorname{Ln}($ no. of on-track) & $\begin{array}{l}-0.112 \\
(0.106)\end{array}$ & $\begin{array}{l}-0.037 \\
(0.103)\end{array}$ & $\begin{array}{l}-0.232 \\
(0.171)\end{array}$ & $\begin{array}{c}-0.71 \\
(0.299)\end{array}$ & $\begin{array}{l}-0.057 \\
(0.138)\end{array}$ \\
\hline Ln(no. of on-track) X Fem. & $\begin{array}{l}-0.112 * * \\
(0.030)\end{array}$ & $\begin{array}{l}-0.137 * * \\
(0.045)\end{array}$ & $\begin{array}{l}-0.166^{*} \\
(0.067)\end{array}$ & $\begin{array}{c}0.010 \\
(0.061)\end{array}$ & $\begin{array}{l}-0.055 \\
(0.077)\end{array}$ \\
\hline \multicolumn{6}{|l|}{$\begin{array}{l}\text { Panel B: Estimated effects in } \\
\% \text {-pts. associated with a } 15 \% \\
\text { increase in no. of on-track }\end{array}$} \\
\hline Women & $-3.14 *$ & $-2.40+$ & $-5.70 *$ & -0.90 & -1.60 \\
\hline Men & -1.57 & -0.50 & -3.20 & -1.00 & -0.80 \\
\hline
\end{tabular}


Table 7: Heterogeneity Analysis - STEM Major Completion for Various Subgroups

\begin{tabular}{|c|c|c|c|}
\hline & $\frac{\text { URM Effect? }}{(1)}$ & $\frac{\text { Low Ability Effect? }}{(2)}$ & $\begin{array}{c}\text { Low SES Effect? } \\
(3)\end{array}$ \\
\hline Panel A: Point Estimates & & & \\
\hline $\operatorname{Ln}($ no. of on-track) & $\begin{array}{l}-0.096 \\
(0.114)\end{array}$ & $\begin{array}{l}-0.116 \\
(0.106)\end{array}$ & $\begin{array}{l}-0.143 \\
(0.119)\end{array}$ \\
\hline Ln(no. of on-track) X Fem. & $\begin{array}{l}-0.125^{*} \\
(0.060)\end{array}$ & $\begin{array}{l}0.802+ \\
(0.472)\end{array}$ & $\begin{array}{l}-0.087 \\
(0.070)\end{array}$ \\
\hline Ln(no. of on-track) X URM & $\begin{array}{l}-0.050 \\
(0.070)\end{array}$ & & \\
\hline Ln(no. of on-track) X Fem. X URM & $\begin{array}{c}0.033 \\
(0.101)\end{array}$ & & \\
\hline $\operatorname{Ln}($ no. of on-track)X bottom $1 / 3$ & & $\begin{array}{c}0.013 \\
(0.064)\end{array}$ & \\
\hline Ln(no. of on-track) X Fem. X bottom $1 / 3$ & & $\begin{array}{l}-0.144+ \\
(0.084)\end{array}$ & \\
\hline Ln(no. of on-track) X Parent col. grad & & & $\begin{array}{c}0.054 \\
(0.063)\end{array}$ \\
\hline Ln(no. of on-track) X Fem. X Parent col. grad & & & $\begin{array}{r}-0.042 \\
(0.087)\end{array}$ \\
\hline \multicolumn{4}{|l|}{$\begin{array}{l}\text { Panel B: Estimated effects in } \\
\% \text {-pts. associated with a } 15 \% \\
\text { increase in no. of on-track }\end{array}$} \\
\hline Non-URM - women & $-3.10 *$ & & \\
\hline Non-URM - men & -1.30 & & \\
\hline URM - women & $-3.30 *$ & & \\
\hline URM - men & -2.00 & & \\
\hline Bottom $1 / 3$ - women & & $-4.00 *$ & \\
\hline Bottom $1 / 3-$ men & & -1.40 & \\
\hline Top 2/3 - women & & -2.00 & \\
\hline Top $2 / 3-$ men & & -1.60 & \\
\hline Col. grad parent - women & & & $-3.00 *$ \\
\hline Col. grad parent - men & & & -1.20 \\
\hline No col. grad parent - women & & & $-3.20 *$ \\
\hline No col. grad parent - men & & & -2.10 \\
\hline Observations & 12,230 & 12,230 & 12,230 \\
\hline
\end{tabular}

Note: Each column is a separate specification. The Column 1 regression also includes a dummy for URM and an interaction term between URM and woman. URM stands for underrepresented minorities and includes all race categories except white, Asian and Indian. The Column 2 regression also includes a dummy for being in the bottom $1 / 3$ of the SAT math distribution and the interaction between being in the bottom and a woman. The Column 3 regression also includes a dummy for having at least one parent with a college degree and the interaction between being that dummy and woman. Additionally, all three regressions include controls for percent female in a class, class size, year and instructor fixed effects, whether the lecture was held in the morning, a vector of student background characteristics, and a student's declared major at entry. Student background characteristics include: gender, race (black, Hispanic, Asian, American Indian, Filipino, Indian and white is the omitted group), if a student went to public high school, if English is the only language spoken in the home, the highest level of education attainment of the parent with the highest level of education, high school grade point average, SAT math and verbal scores and age. Clustered standard errors are in parentheses, ${ }^{* *} \mathrm{p}<0.01, * \mathrm{p}<0.05,+\mathrm{p}<0.1$. Clusters are by CHEM1A lecture (class). A $15 \%$ increase in number of on-track students in a class is the equivalent of increasing the number of on-track students by about 1 standard deviation (44 students). 
Table 8: The Effect of the Number of On-Track Students on CHEM1A Grade

\begin{tabular}{|c|c|c|c|c|c|c|c|}
\hline & $\frac{\text { Full Sample }}{(1)}$ & $\frac{\text { Lectures }>100}{(2)}$ & $\frac{\text { Non-URMs }}{(3)}$ & $\frac{\text { URMs }}{(4)}$ & $\frac{\text { Bottom 1/3 }}{(5)}$ & $\frac{\text { Middle } 1 / 3}{(6)}$ & $\frac{\text { Top } 1 / 3}{(7)}$ \\
\hline \multicolumn{8}{|l|}{ Panel A: Point Estimates } \\
\hline $\operatorname{Ln}($ no. of on-track) & $\begin{array}{l}0.831+ \\
(0.441)\end{array}$ & $\begin{array}{l}0.856+ \\
(0.447)\end{array}$ & $\begin{array}{l}0.799+ \\
(0.431)\end{array}$ & $\begin{array}{l}1.005+ \\
(0.546)\end{array}$ & $\begin{array}{l}1.376 * \\
(0.610)\end{array}$ & $\begin{array}{l}0.893 * \\
(0.416)\end{array}$ & $\begin{array}{c}0.766+ \\
(0.453)\end{array}$ \\
\hline Ln(no. of on-track) X Fem. & $\begin{array}{c}0.029 \\
(0.068)\end{array}$ & $\begin{array}{c}0.005 \\
(0.125)\end{array}$ & $\begin{array}{c}0.036 \\
(0.087)\end{array}$ & $\begin{array}{c}0.010 \\
(0.111)\end{array}$ & $\begin{array}{l}-0.079 \\
(0.092)\end{array}$ & $\begin{array}{l}-0.092 \\
(0.119)\end{array}$ & $\begin{array}{c}0.121 \\
(0.148)\end{array}$ \\
\hline Instructor, Year, Time of day FE & $\mathrm{X}$ & $\mathrm{X}$ & $\mathrm{X}$ & $\mathrm{X}$ & $\mathrm{X}$ & $\mathrm{X}$ & $\mathrm{X}$ \\
\hline Student Characteristics & $X$ & $\mathrm{X}$ & $\mathrm{X}$ & $\mathrm{X}$ & $X$ & $\mathrm{X}$ & $X$ \\
\hline \multicolumn{8}{|l|}{$\begin{array}{l}\text { Panel B: Estimated effects in } \\
\% \text {-pts. associated with a } 15 \% \\
\text { increase in no. of on-track } \\
(0.3 \text { grade points = } 1 \text { letter grade) }\end{array}$} \\
\hline Women & $0.12+$ & $0.12+$ & $0.11+$ & $0.14+$ & $0.18 *$ & $0.11^{*}$ & $0.12 *$ \\
\hline Men & $0.12+$ & $0.12+$ & $0.11+$ & $0.14+$ & $0.19 *$ & $0.13 *$ & $0.11+$ \\
\hline Observations & 12,230 & 12,122 & 8,281 & 3,949 & 4,206 & 3,438 & 4,586 \\
\hline
\end{tabular}


Table 9: STEM Major Completion - Controls for CHEM1A Grade

\begin{tabular}{lccc}
\hline \hline & Full Sample & Lectures $>100$ \\
\cline { 2 - 2 } Panel A: Point Estimates & $(1)$ & $(2)$ \\
Ln(no. of on-track) & $-0.256+$ & -0.185 \\
& $(0.140)$ & $(0.139)$ \\
Ln(no. of on-track) X Fem. & $-0.117^{* *}$ & $-0.138^{* *}$ \\
& $(0.034)$ & $(0.053)$ \\
CHEM1A Grade & $0.169^{* *}$ & $0.169 * *$ \\
& $(0.005)$ & $(0.005)$ \\
Instructor, Year, Time of day FE & $\mathrm{X}$ & $\mathrm{X}$ \\
Student Characteristics & $\mathrm{X}$ & $\mathrm{X}$ \\
\hline Panel B: Estimated effects in & & \\
\%-pts. associated with a 15\% & & \\
increase in no. of on-track & & $-4.50^{*}$ \\
Women & $-5.20 * *$ & 12,122 \\
Men & $-3.60+$ & 12,230 & \\
Observations & & \\
\hline \hline
\end{tabular}

Note: Each column is a separate specification. Controls include percent female in a class, log class size, year and instructor fixed effects, whether the lecture was held in the morning, a vector of student background characteristics, and a student's declared major at entry. Student background characteristics include: gender, race (black, Hispanic, Asian, American Indian, Filipino, Indian and white is the omitted group), if a student went to public high school, if English is the only language spoken in the home, the highest level of education attainment of the parent with the highest level of education, high school grade point average, SAT math and verbal scores and age. Clustered standard errors are in parentheses, $* * \mathrm{p}<0.01, * \mathrm{p}<0.05$, $+\mathrm{p}<0.1$. Clusters are by CHEM1A lecture (class). A $15 \%$ increase in number of on-track students in a class is the equivalent of increasing the number of on-track students by about 1 standard deviation (44 students). URM stands for underrepresented minorities and includes all race categories except white, Asian and Indian. 
Table 10: The Effect of the Number of On-Track Students on CHEM1B Enrollment

\begin{tabular}{|c|c|c|c|c|c|c|c|}
\hline & $\frac{\text { Full Sample }}{(1)}$ & $\frac{\text { Lectures }>100}{(2)}$ & $\frac{\text { Non-URMs }}{(3)}$ & $\frac{\text { URMs }}{(4)}$ & $\frac{\text { Bottom 1/3 }}{(5)}$ & $\frac{\text { Middle } 1 / 3}{(6)}$ & $\frac{\text { Top } 1 / 3}{(7)}$ \\
\hline \multicolumn{8}{|l|}{ Panel A: Point Estimates } \\
\hline $\operatorname{Ln}($ no. of on-track) & $\begin{array}{c}0.000 \\
(0.086)\end{array}$ & $\begin{array}{c}0.015 \\
(0.093)\end{array}$ & $\begin{array}{l}-0.039 \\
(0.065)\end{array}$ & $\begin{array}{c}0.110 \\
(0.191)\end{array}$ & $\begin{array}{l}-0.221 \\
(0.167)\end{array}$ & $\begin{array}{c}0.141 \\
(0.160)\end{array}$ & $\begin{array}{c}0.125 \\
(0.110)\end{array}$ \\
\hline Ln(no. of on-track) X Fem. & $\begin{array}{c}-0.045^{*} \\
(0.019)\end{array}$ & $\begin{array}{c}-0.058+ \\
(0.031)\end{array}$ & $\begin{array}{l}-0.049 \\
(0.037)\end{array}$ & $\begin{array}{l}-0.025 \\
(0.051)\end{array}$ & $\begin{array}{c}-0.098+ \\
(0.050)\end{array}$ & $\begin{array}{c}0.040 \\
(0.044)\end{array}$ & $\begin{array}{l}-0.035 \\
(0.047)\end{array}$ \\
\hline Instructor, Year, Time of day FE & $\mathrm{X}$ & $\mathrm{X}$ & $\mathrm{X}$ & $\mathrm{X}$ & $\mathrm{X}$ & $\mathrm{X}$ & X \\
\hline Student Characteristics & $\mathrm{X}$ & $\mathrm{X}$ & $\mathrm{X}$ & $\mathrm{X}$ & $X$ & $\mathrm{X}$ & $\mathrm{X}$ \\
\hline \multicolumn{8}{|l|}{$\begin{array}{l}\text { Panel B: Estimated effects in } \\
\% \text {-pts. associated with a } 15 \% \\
\text { increase in no. of on-track } \\
(0.3 \text { grade points = } 1 \text { letter grade })\end{array}$} \\
\hline Women & -0.60 & -0.60 & -1.10 & 1.20 & $-4.50 *$ & 2.50 & 1.30 \\
\hline Men & 0.01 & 0.20 & -0.40 & 1.50 & -3.10 & 2.00 & 1.60 \\
\hline Observations & 12,230 & 12,122 & 8,281 & 3,949 & 4,206 & 3,438 & 4,586 \\
\hline
\end{tabular}


Table 11: The Effect of the Number of On-Track Students on CHEM1B Grade

\begin{tabular}{|c|c|c|c|c|c|c|c|}
\hline & $\frac{\text { Full Sample }}{(1)}$ & $\frac{\text { Lectures }>100}{(2)}$ & $\frac{\text { Non-URMs }}{(3)}$ & $\frac{\text { URMs }}{(4)}$ & $\frac{\text { Bottom } 1 / 3}{(5)}$ & $\frac{\text { Middle } 1 / 3}{(6)}$ & $\frac{\text { Top } 1 / 3}{(7)}$ \\
\hline \multicolumn{8}{|l|}{ Panel A: Point Estimates } \\
\hline $\operatorname{Ln}($ no. of on-track) & $\begin{array}{l}-0.431 \\
(0.260)\end{array}$ & $\begin{array}{l}-0.374 \\
(0.281)\end{array}$ & $\begin{array}{l}-0.288 \\
(0.320)\end{array}$ & $\begin{array}{c}-0.660 * \\
(0.287)\end{array}$ & $\begin{array}{l}-0.208 \\
(0.373)\end{array}$ & $\begin{array}{l}-0.625 \\
(0.585)\end{array}$ & $\begin{array}{l}-0.555+ \\
(0.276)\end{array}$ \\
\hline Ln(no. of on-track) X Fem. & $\begin{array}{c}-0.130+ \\
(0.067)\end{array}$ & $\begin{array}{c}-0.205^{*} \\
(0.099)\end{array}$ & $\begin{array}{c}-0.163+ \\
(0.085)\end{array}$ & $\begin{array}{l}-0.156 \\
(0.143)\end{array}$ & $\begin{array}{l}-0.096 \\
(0.131)\end{array}$ & $\begin{array}{l}-0.244 \\
(0.169)\end{array}$ & $\begin{array}{c}0.136 \\
(0.132)\end{array}$ \\
\hline Instructor, Year, Time of day FE & $\mathrm{X}$ & X & X & $\mathrm{X}$ & X & $\mathrm{X}$ & $\mathrm{X}$ \\
\hline Student Characteristics & $\mathrm{X}$ & $\mathrm{X}$ & $\mathrm{X}$ & $\mathrm{X}$ & $X$ & $\mathrm{X}$ & $X$ \\
\hline \multicolumn{8}{|l|}{$\begin{array}{l}\text { Panel B: Estimated effects in } \\
\% \text {-pts. associated with a } 15 \% \\
\text { increase in no. of on-track } \\
(0.3 \text { grade points = } 1 \text { letter grade) }\end{array}$} \\
\hline Women & $-0.08 *$ & $-0.08^{*}$ & -0.06 & $-0.11 *$ & -0.04 & -0.12 & -0.06 \\
\hline Men & -0.06 & -0.05 & -0.04 & $-0.09 *$ & -0.03 & -0.09 & $-0.08^{*}$ \\
\hline Observations & 10,086 & 10,003 & 6,942 & 3,144 & 3,187 & 2,857 & 4,042 \\
\hline
\end{tabular}


Table 12: Where are the Women Going?

\begin{tabular}{lcc}
\hline \hline & Graduate in Non-STEM & Graduate \\
Panel A: Point Estimates & $(1)$ & $(2)$ \\
Ln(no. of on-track) & 1.22 & -0.035 \\
& $(0.099)$ & $(0.113)$ \\
Ln(no. of on-track) X Fem. & $0.107^{* *}$ & $-0.074+$ \\
& $(0.030)$ & $(0.038)$ \\
Instructor, Year, Time of day FE & $\mathrm{X}$ & $\mathrm{X}$ \\
Student Characteristics & $\mathrm{X}$ & $\mathrm{X}$ \\
\hline Panel B: Estimated effects in & & \\
\%-pts. associated with a 15\% & & \\
increase in no. of on-track & $3.20 *$ & -0.50 \\
Women & 1.70 & -1.50 \\
Men & 12,230 & 12,230 \\
Observations & & \\
\hline \hline
\end{tabular}

Note: Each column is a separate specification. Controls include percent female in a class, log class size, year and instructor fixed effects, whether the lecture was held in the morning, a vector of student background characteristics, and a student's declared major at entry. Student background characteristics include: gender, race (black, Hispanic, Asian, American Indian, Filipino, Indian and white is the omitted group), if a student went to public high school, if English is the only language spoken in the home, the highest level of education attainment of the parent with the highest level of education, high school grade point average, SAT math and verbal scores and age. Clustered standard errors are in parentheses , ** $\mathrm{p}<0.01, * \mathrm{p}<0.05,+\mathrm{p}<0.1$. Clusters are by CHEM1A lecture (class). A $15 \%$ increase in number of on-track students in a class is the equivalent of increasing the number of on-track students by about 1 standard deviation (44 students). URM stands for underrepresented minorities and includes all race categories except white, Asian and Indian. 


\section{Appendix}

Table A1: STEM Majors

\begin{tabular}{ll}
\hline \hline Major Requires CHEM1A & STEM Majors \\
\hline X & Biology \\
X & Biochemistry \\
X & Biopsychology \\
X & Chemistry \\
X & Engineering \\
X & Computer Engineering \\
& Computer Science \\
X & Earth Science \\
X & Ecology \\
X & Environmental Science \\
& Mathematics \\
X & Statistics \\
X & Geophysics \\
X & Hydrology \\
X & Zoology \\
X & Pharmacology \\
X & Physics \\
X & Physiology \\
\hline \hline
\end{tabular}


Table A2: Balance Test - Orientation Attendees vs. Non-Attendees

\begin{tabular}{|c|c|c|c|}
\hline & $\frac{\text { Summer Orientation Group }}{(1)}$ & $\begin{array}{c}\text { Did Not Attend Orientation } \\
(2)\end{array}$ & $\frac{\text { Diff. (1) - (2) }}{(3)}$ \\
\hline \multicolumn{4}{|c|}{ Student Background and Class Characteristics } \\
\hline No. On-track is above median & $\begin{array}{c}0.48 \\
(0.01)\end{array}$ & $\begin{array}{c}0.46 \\
(0.04)\end{array}$ & $\begin{array}{c}0.02 \\
(0.04)\end{array}$ \\
\hline Lecture is at 8 or 9 a.m. & $\begin{array}{l}0.35 \\
(0.01)\end{array}$ & $\begin{array}{c}0.39 \\
(0.04)\end{array}$ & $\begin{array}{l}-0.04 \\
(0.04)\end{array}$ \\
\hline Female & $\begin{array}{c}0.49 \\
(0.01)\end{array}$ & $\begin{array}{c}0.52 \\
(0.04)\end{array}$ & $\begin{array}{l}-0.03 \\
(0.04)\end{array}$ \\
\hline URM (underrepresented minority) & $\begin{array}{c}0.38 \\
(0.01)\end{array}$ & $\begin{array}{c}0.48 \\
(0.04)\end{array}$ & $\begin{array}{l}-0.10^{*} \\
(0.04)\end{array}$ \\
\hline High school GPA is above median & $\begin{array}{c}0.51 \\
(0.01)\end{array}$ & $\begin{array}{c}0.46 \\
(0.04)\end{array}$ & $\begin{array}{l}-0.05 \\
(0.04)\end{array}$ \\
\hline SAT math score is above median & $\begin{array}{c}0.51 \\
(0.01)\end{array}$ & $\begin{array}{c}0.51 \\
(0.04)\end{array}$ & $\begin{array}{c}0.00 \\
(0.04)\end{array}$ \\
\hline SAT verbal score is above median & $\begin{array}{c}0.54 \\
(0.01)\end{array}$ & $\begin{array}{c}0.48 \\
(0.04)\end{array}$ & $\begin{array}{c}0.06 \\
(0.04)\end{array}$ \\
\hline Attended public high school & $\begin{array}{c}0.92 \\
(0.01)\end{array}$ & $\begin{array}{c}0.93 \\
(0.02)\end{array}$ & $\begin{array}{l}-0.01 \\
(0.02)\end{array}$ \\
\hline English is only language spoken in home & $\begin{array}{c}0.54 \\
(0.01)\end{array}$ & $\begin{array}{c}0.48 \\
(0.04)\end{array}$ & $\begin{array}{c}0.06 \\
(0.04)\end{array}$ \\
\hline No parent graduated from college & $\begin{array}{c}0.37 \\
(0.01)\end{array}$ & $\begin{array}{c}0.43 \\
(0.04)\end{array}$ & $\begin{array}{l}-0.05 \\
(0.04)\end{array}$ \\
\hline Observations & 1,624 & 178 & 1,802 \\
\hline
\end{tabular}

Note: URM stands for underrepresented minorities and includes all race categories except white, Asian and Indian. Column 3 uses an asterisk system to denote whether the differences in means are significant. Level of significance is indicated as follows: $* * \mathrm{p}<0.01, * \mathrm{p}<0.05,+\mathrm{p}<0.1$. Standard deviations are in parentheses. The sample includes only those students enrolled in the first quarter of General Chemistry (CHEM1A) in the fall quarter of their freshman year at UCSB for the year 2013. 
Table A3: The Effect of the Number of On-Track Students on STEM Major Completion Including Various Controls

\begin{tabular}{|c|c|c|c|c|}
\hline & (1) & $(2)$ & (3) & (4) \\
\hline \multicolumn{5}{|l|}{ Panel A: Point Estimates } \\
\hline $\operatorname{Ln}($ no. of on-track) & $\begin{array}{c}-0.262 * \\
(0.128)\end{array}$ & $\begin{array}{c}-0.347 * \\
(0.138)\end{array}$ & $\begin{array}{c}-0.211^{*} \\
(0.102)\end{array}$ & $\begin{array}{r}-0.112 \\
(0.106)\end{array}$ \\
\hline Ln(no. of on-track) X Fem. & $\begin{array}{l}-0.085^{*} \\
(0.034))\end{array}$ & $\begin{array}{c}-0.098 * * \\
(0.029)\end{array}$ & $\begin{array}{c}-0.103 * * \\
(0.029)\end{array}$ & $\begin{array}{c}-0.112 * * \\
(0.030)\end{array}$ \\
\hline Year FE & $\mathrm{X}$ & $\mathrm{X}$ & $\mathrm{X}$ & X \\
\hline Instructor FE & & $\mathrm{X}$ & $\mathrm{X}$ & $\mathrm{X}$ \\
\hline Time of day FE & & & $X$ & $X$ \\
\hline Student Characteristics & & & & $\mathrm{X}$ \\
\hline \multicolumn{5}{|l|}{$\begin{array}{l}\text { Panel B: Estimated effects in } \\
\% \text {-pts. associated with a } 15 \% \\
\text { increase in no. of on-track }\end{array}$} \\
\hline Women & $-4.85 * *$ & $-6.23 * *$ & $-4.40 * *$ & $-3.14 *$ \\
\hline Men & $-3.66^{*}$ & $-4.86 * *$ & $-2.95+$ & -1.57 \\
\hline Observations & 12,230 & 12,230 & 12,230 & 12,230 \\
\hline \multicolumn{5}{|c|}{$\begin{array}{l}\text { Note: Each column is a separate specification. Controls include percent female in a class, log class size, year and } \\
\text { instructor fixed effects, whether the lecture was held in the morning, a vector of student background characteristics, } \\
\text { and a student's declared major at entry. Student background characteristics include: gender, race (black, Hispanic, } \\
\text { Asian, American Indian, Filipino, Indian and white is the omitted group), if a student went to public high school, } \\
\text { if English is the only language spoken in the home, the highest level of education attainment of the parent with } \\
\text { the highest level of education, high school grade point average, SAT math and verbal scores and age. Clustered } \\
\text { standard errors are in parentheses, } * * \text { p }<0.01, * \text { p }<0.05,+p<0.1 \text {. Clusters are by CHEM1A lecture (class). A } \\
15 \% \text { increase in number of on-track students in a class is the equivalent of increasing the number of on-track } \\
\text { students by about } 1 \text { standard deviation (44 students). URM stands for underrepresented minorities and includes } \\
\text { all race categories except white, Asian and Indian. }\end{array}$} \\
\hline
\end{tabular}


Table A4: The Effect of Percent On-Track in a Class on STEM Major Completion

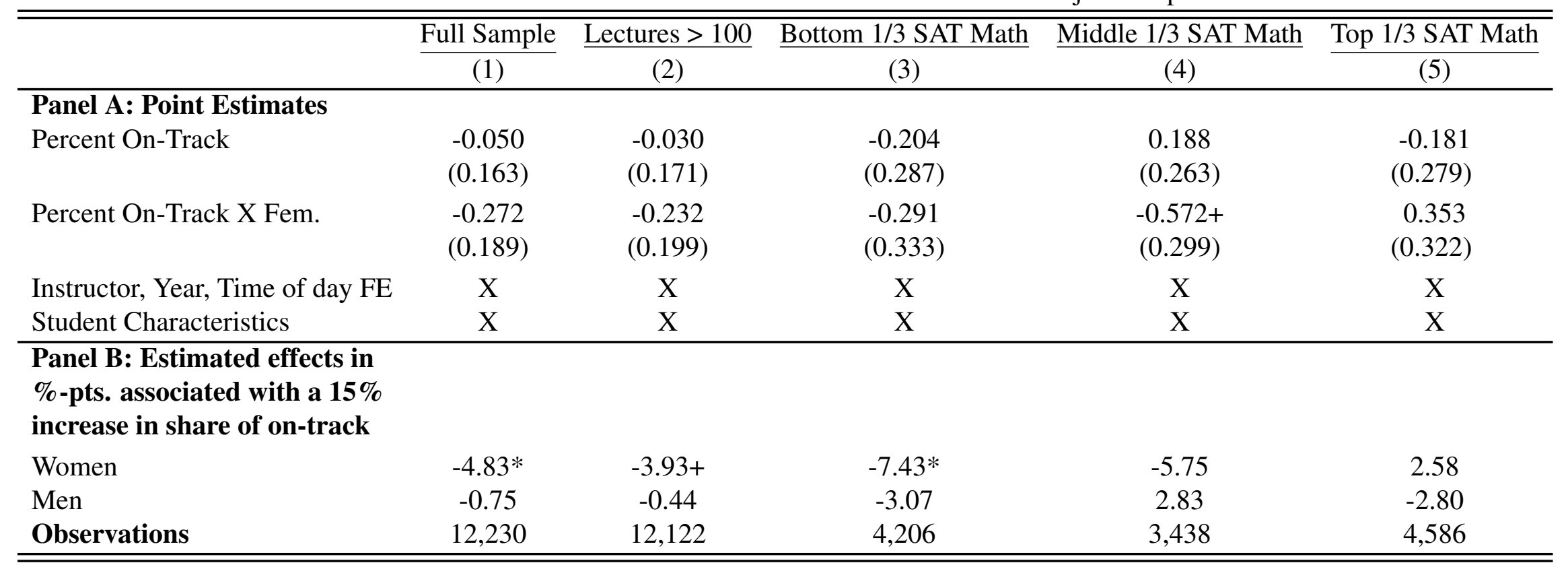

Note: Each column is a separate specification. Controls include percent female in a class, year and instructor fixed effects, whether the lecture was held in the morning, a vector of student background characteristics, and a student's declared major at entry. Student background characteristics include: gender, race (black, Hispanic, Asian, American Indian, Filipino, Indian and white is the omitted group), if a student went to public high school, if English is the only language spoken in the home, the highest level of education attainment of the parent with the highest level of education, high school grade point average, SAT math and verbal scores and age. Clustered standard errors are in parentheses, $* * \mathrm{p}<0.01,{ }^{*} \mathrm{p}<0.05,+\mathrm{p}<0.1$. Clusters are by CHEM1A lecture (class). URM stands for underrepresented minorities and includes all race categories except white, Asian and Indian. 
Table A5: The Effect of Class Average Predicted CHEM1A Grade on STEM Major Completion

\begin{tabular}{|c|c|c|c|c|c|}
\hline & $\frac{\text { Full Sample }}{(1)}$ & $\frac{\text { Lectures }>100}{(2)}$ & $\frac{\text { Bottom 1/3 SAT Math }}{(3)}$ & $\frac{\text { Middle 1/3 SAT Math }}{(4)}$ & $\frac{\text { Top 1/3 SAT Math }}{(5)}$ \\
\hline \multicolumn{6}{|l|}{ Panel A: Point Estimates } \\
\hline Ave. Predicted CHEM1A Grade & $\begin{array}{c}-0.136 * * \\
(0.048)\end{array}$ & $\begin{array}{c}-0.142 * * \\
(0.052)\end{array}$ & $\begin{array}{l}-0.0439 \\
(0.103)\end{array}$ & $\begin{array}{l}-0.298 * \\
(0.116)\end{array}$ & $\begin{array}{l}-0.0545 \\
(0.094)\end{array}$ \\
\hline Ave. Predicted Grade X Fem. & $\begin{array}{c}-0.130 * * \\
(0.039)\end{array}$ & $\begin{array}{c}-0.121 * * \\
(0.046)\end{array}$ & $\begin{array}{l}-0.146 \\
(0.094)\end{array}$ & $\begin{array}{l}-0.010 \\
(0.091)\end{array}$ & $\begin{array}{l}-0.113 \\
(0.074)\end{array}$ \\
\hline \multicolumn{6}{|l|}{$\begin{array}{l}\text { Panel B: Estimated effects in } \\
\% \text {-pts. associated with a } 0.19 \\
\text { increase in ave. predicted grade }\end{array}$} \\
\hline Women & $-5.04 * *$ & $-5.00 * *$ & $-3.60+$ & $-5.85 * *$ & -3.17 \\
\hline Men & $-2.58 *$ & $-2.71 *$ & -0.83 & $-5.66 * *$ & -1.03 \\
\hline
\end{tabular}

Note: Each column is a separate specification. Controls include percent female in a class, log class size, year and instructor fixed effects, whether the lecture was held in the morning, a vector of student background characteristics, and a student's declared major at entry. Student background characteristics include: gender, race (black, Hispanic, Asian, American Indian, Filipino, Indian and white is the omitted group), if a student went to public high school, if English is the only language spoken in the home, the highest level of education attainment of the parent with the highest level of education, high school grade point average, SAT math and verbal scores and age. Bootstrapped standard errors are in parentheses, ${ }^{* *} \mathrm{p}<0.01,{ }^{*} \mathrm{p}<0.05,+\mathrm{p}<0.1$. A 0.19 increase in average predicted grade is the equivalent of increasing the average predicted grade by a standard deviation. URM stands for underrepresented minorities and includes all race categories except white, Asian and Indian. 
Table A6: The Effect of the Number of On-Track Students on STEM Major Completion for Various Groups

\begin{tabular}{|c|c|c|c|c|c|}
\hline & \multirow{2}{*}{$\begin{array}{c}\underline{\text { Late-Track }} \\
\text { (1) }\end{array}$} & \multirow{2}{*}{$\begin{array}{c}\text { Late-Track \& On-Track } \\
\text { (2) }\end{array}$} & \multicolumn{3}{|c|}{ Late-Track \& On-Track } \\
\hline & & & $\frac{\text { Bottom } 1 / 3}{(3)}$ & $\frac{\text { Middle } 1 / 3}{(4)}$ & $\frac{\text { Top } 1 / 3}{(5)}$ \\
\hline \multicolumn{6}{|l|}{ Panel A: Point Estimates } \\
\hline $\operatorname{Ln}($ no. of on-track) & $\begin{array}{l}-0.279 \\
(0.190)\end{array}$ & $\begin{array}{l}-0.143 \\
(0.088)\end{array}$ & $\begin{array}{l}-0.206 \\
(0.152)\end{array}$ & $\begin{array}{l}-0.135 \\
(0.291)\end{array}$ & $\begin{array}{c}-0.081 \\
(0.133)\end{array}$ \\
\hline Ln(no. of on-track) X Fem. & $\begin{array}{c}-0.150+ \\
(0.083)\end{array}$ & $\begin{array}{c}-0.117 * * \\
(0.031)\end{array}$ & $\begin{array}{c}-0.162 * * \\
(0.048)\end{array}$ & $\begin{array}{c}-0.013 \\
(0.076)\end{array}$ & $\begin{array}{l}-0.115+ \\
(0.065)\end{array}$ \\
\hline Instructor, Year, Time of day FE & $X$ & $\mathrm{X}$ & $\mathrm{X}$ & $\mathrm{X}$ & $\mathrm{X}$ \\
\hline Student Characteristics & $\mathrm{X}$ & $\mathrm{X}$ & $\mathrm{X}$ & $\mathrm{X}$ & $\mathrm{X}$ \\
\hline \multicolumn{6}{|l|}{$\begin{array}{l}\text { Panel B: Estimated effects in } \\
\% \text {-pts. associated with a } 15 \% \\
\text { increase in no. of on-track }\end{array}$} \\
\hline Women & $-6.00 *$ & $-3.64 * *$ & $-5.15^{*}$ & -2.07 & -2.74 \\
\hline Men & -3.91 & -2.00 & -2.89 & -1.90 & -1.13 \\
\hline Observations & 1,935 & 14,165 & 4,770 & 3,389 & 5,556 \\
\hline
\end{tabular}

Note: Each column is a separate specification. "Bottom 1/3" refers to the bottom $1 / 3$ of the SAT math distribution. "Middle 1/3" and "Top 1/3" refer to the middle $1 / 3$ and top $1 / 3$ of the SAT math distribution for the class respectively. Columns 3-5 include both on-track and late-track students. Controls include percent female in a class, log class size, year and instructor fixed effects, whether the lecture was held in the morning, a vector of student background characteristics, and a student's declared major at entry. Student background characteristics include: gender, race (black, Hispanic, Asian, American Indian, Filipino, Indian and white is the omitted group), if a student went to public high school, if English is the only language spoken in the home, the highest level of education attainment of the parent with the highest level of education, high school grade point average, SAT math and verbal scores and age. Clustered standard errors are in parentheses, $* * \mathrm{p}<0.01,{ }^{*} \mathrm{p}<0.05$ $+\mathrm{p}<0.1$. Clusters are by CHEM1A lecture (class). A $15 \%$ increase in number of on-track students in a class is the equivalent of increasing the number of on-track students by about 1 standard deviation (44 students). URM stands for underrepresented minorities and includes all race categories except white, Asian and Indian. 
Table A7: Major Composition by Gender (\%)

\begin{tabular}{lcccc}
\hline \hline & \multicolumn{1}{l}{$\begin{array}{l}\text { Women } \\
\end{array}$} & & $\underline{\text { Men }}$ & \\
& Intended Major at Entry & Major at Grad. & Intended Major at Entry & Major at Grad. \\
\hline Hard Science & 15.07 & 14.29 & 49.37 & 33.77 \\
Bio/Environ. Sci. & 51.81 & 29.88 & 24.84 & 17.45 \\
Social Science & 3.48 & 19.27 & 2.79 & 15.79 \\
Human./Arts/Interd. & 3.08 & 36.57 & 2.55 & 32.97 \\
Undeclared & 26.55 & 0.00 & 20.45 & 0.01 \\
\hline \hline
\end{tabular}

Note: See Appendix Table A8 for the majors that fall into each major category: hard science, biology/environmental studies, social sciences, and humanities/arts/interdisciplinary. The sample includes only those students enrolled in the first quarter of General Chemistry (CHEM1A) in the fall quarter of their freshman year at UCSB between the years 1997 and 2007. 
Table A8: Majors by Category

\begin{tabular}{|c|c|c|c|}
\hline Hard Sci. & Bio \& Env. Studies & Social Sci. & Human., Arts, \& Interdis. \\
\hline Biochemistry & Biochemistry-Molecular Biology & Anthropology & Art History \\
\hline Chemistry & Biological Sciences & Geography & Art Studio \\
\hline Chemical Engineering & Biopsychology & Geophysics & Asian \& American Studies \\
\hline Computer Engineering & Physiology & Physical Geography & Asian Studies \\
\hline Electrical Engineering & Biology & Economics-Accounting & Black Studies \\
\hline Earth Science & Cell \& Develp. Biology & Economics-Mathematics & Chicana and Chicano Studies \\
\hline Hydrological Sciences & Microbiology & Economics & Chinese \\
\hline Mechanical Engineering & Environmental Studies & Political Science & Classics \\
\hline Pharmacology & & Psychology & Communication Studies \\
\hline Physics & & Sociology & Comparative Literature \\
\hline Computer Science & & Business Economics & Creative Studies \\
\hline Mathematics & & & Dance \\
\hline Financial Math \& Stats & & & Dramatic Art \\
\hline Statistics & & & English \\
\hline Zoology & & & Feminist Studies \\
\hline Aquatic Biology & & & Film \& Media Studies \\
\hline Ecology and Evolution & & & Financial Mathematics \& Statistics \\
\hline \multirow[t]{19}{*}{ Computer Science } & & & French \\
\hline & & & Germanic Languages \\
\hline & & & Global Studies \\
\hline & & & History or History of Public Policy \\
\hline & & & Interdisciplinary Studies \\
\hline & & & Italian Cultural Studies \\
\hline & & & Japanese \\
\hline & & & Language, Culture \& Society \\
\hline & & & Latin Am/Iberian Studies \\
\hline & & & Law \& Society \\
\hline & & & Linguistics \\
\hline & & & Medieval Studies \\
\hline & & & Middle Eastern Studies \\
\hline & & & Music \& Music Composition \\
\hline & & & Philosophy \\
\hline & & & Portuguese \\
\hline & & & Religious Studies \\
\hline & & & Slavic Languages \& Literatures \\
\hline & & & Spanish \\
\hline
\end{tabular}

